\title{
Introduction: Spanish Banking-How Do We Explain a History of Fragility?
}

\section{INTRODUCTION}

This book examines the "fragility" and historical crises proneness of the Spanish banking system, with a particular focus on the most recent banking crisis that followed the global financial crisis of 2008. It borrows and builds on the arguments developed by Calomiris and Haber (2014) who have argued that banking systems arise from a process of political bargaining: Every country's banking system is the result of what they call a Game of Bank Bargains - a game in which actors with differentiated interests come together to form coalitions that will determine how banking systems are created and how they will operate: "Banks' strengths and shortcomings are the predictable consequence of political bargains and those bargains are structured by a society's fundamental political institutions" (p. x). ${ }^{1}$ Each country is different: It has different rules of the game, specific players with distinctive interests, governments who get different shares of the benefits, and coalitions that forge specific "bank banking

\footnotetext{
${ }^{1}$ In their magisterial comparative analysis of banking systems that focuses on the United States, England, Canada, Mexico, and Brazil, Calomiris and Haber invite other scholars to test their framework "against additional country cases" $(2014$, p. 25) hoping that other scholars would evaluate their interpretations by comparing them with detailed narratives of other countries. This book takes that invitation and applies their framework and arguments to the Spanish case.
}

(C) The Author(s) 2020

S. Royo, Why Banks Fail, https://doi.org/10.1057/978-1-137-53228-2_1 
bargains." According to them, banking systems are the result of political struggles ("bank bargains") between government, voters, and interest groups. The Game of Bank Bargains determines the rules that define how banks are regulated, how they are chartered, and how they interact with the state. These outcomes, in turn, determine banking system's performance along two dimensions: propensity for banking crisis and the degree of private access to credit (p. 477). These authors focus on the structure of the banking system and the rules for allocating credit as the key explanation for banking instability, and in order to explain why banking systems vary in structure, they identify two key variables, regime type and the presence or absence of a populist coalition.

Calomiris and Haber $(2014$, p. 454) define abundant credit as a ratio of private bank credit to GDP of about $83 \%$ over the $1990-2010$ period, and a stable banking system as one that has been crises-free since 1970 . According to that definition, only six out of 117 countries meet that threshold: Australia, Canada, Hong Kong, Malta, New Zealand, and Singapore. This book aims to explain outcomes in this "Game of Bank Bargains" in a particular country, Spain, which has suffered two major banking crises since the 1970s. ${ }^{2}$ It seeks to answer one fundamental question: Why has Spain not been able to construct a banking system that avoids banking crises? In answering this question, the main focus will be on political factors, and in particular in the interplay between politics and banking, which has been crucial to account for the performance of the Spanish banking system.

The book examines the historical circumstances that have shaped the formation of political institutions and coalitions that control banking outcomes in Spain. Those circumstances are crucial to determine the extent to which Spain has suffered banking crises and suffered scarce credit, and they depend on the historical context, which changes as a result of external influences (for instance, banking crises have arisen from political struggles). Yet, these circumstances are mediated by political institutions (for instance, they may be able to insulate banking systems from populist policies). Following Calomiris and Haber (2014, pp. 488-89), it looks at political preconditions on banking-system outcomes, but accepts that banking systems also shape politics as well: Banking systems are not just an outcome of politics, they also shape the coalitions that bargain and affect

${ }^{2}$ I also adopt Calomiris and Haber's definition of banking crises. They regard them as "either systemic insolvency crises or systemic illiquidity crises" (p. 5, footnote 1). 
the bargaining power of the parties that participate in the bargain. Finally, political circumstances influence innovations, which shape the development of new financial services and instruments. The main argument of the book is that political circumstances influence bank banking bargains, and that they, in turn, define the types of banks that emerged in the country. It seeks to explain banking goals and how they are shaped by political bargains, not the extend of regulation, but rather on the goals that give rise to regulation (p. 14).

In regard to the most recent Spanish banking crises of 2008, the main hypothesis is that this financial crisis was first and foremost the outcome of a political bargain. A central argument of this book is that politics matter, and that political factors are central to understanding why Spain has suffered repeated banking crises. It starts from the premise that banks are not just institutions run and controlled by technocrats who make mistakes, and also that banking crises are not merely the results of such mistakes, or incompetence, bad luck, or moral shortcomings. On the contrary, this book shows how politics (understood as the political institutions that structure the incentives of economic and social actors) influence bankers' decisions, their operations, and the regulatory framework in which they operate. Indeed, political institutions and politics structure the incentives of actors involved in banks, from bankers to shareholders, depositors, debtors, to regulators. In other words, banking crises are the consequence of banks' characteristics and the political circumstances in which they operate (see Calomiris and Haber 2014).

As we will see below, financial crises are devastating. Despite this, and this is the puzzle that this book seeks to address, in countries like Spain these crises have been persistent throughout history and governments have been unable, or unwilling, to make sure that banks either limit their risk exposure and/or have sufficient capitalization. When governments deal with banking decisions, they often face conflicts of interest, and different groups will have distinctive preferences and leverage (based on their wealth and power) to influence those decisions. The way(s) in which governments resolve or mediate those conflicts, and the resulting coalitions that emerge from the bargaining process, will largely determine the strength (or fragility) of the resulting banking structure.

Governments are indeed essential because they regulate banks, they enforce contracts, they use banks as source of finance, and in the case of bailouts, they allocate losses among creditors. But other groups (e.g., bankers, shareholders, depositors, debtors, taxpayers) also have 'skins in 
the game' and have a stake in the performance of banks. The interplay of these actors (what Calomiris and Haber call the "Game of Bank Bargaining") will lead to coalitions that will determine bank entry rules, the degree of competition in the sector, credit flows, credit conditions, banks' activities, and the allocation of loses. Different bank structure configurations have different beneficiaries and losers among those stakeholders, and the outcome of the political struggle among them will determine the role that they will play in the financial system. This book seeks to explain how this struggle/bargaining process (what they call the "banking games") has played out in Spain in order to explain how banking rules have emerged in the country, and how the players have operated under those rules (Calomiris and Haber 2014, pp. 12-15).

To do so, the book traces the coevolution of banking and politics in Spain over time, with a particular focus on the two decades that preceded the 2008 crisis; and it seeks to test Calomiris and Haber's hypotheses (2014, p. 453): Democracies are more conductive to a broad distribution of bank credit than autocracies; democracies with liberal institutions are more conductive to broad distribution of credit and the absence of banking crisis than those in which bankers form coalitions with populists; and government safety nets tend to destabilize banking systems, and they arise as a result of political bargains, not for economic efficiency reasons. In other words, it will test the hypothesis that stable democracies, like Spain's, with weak institutions that cannot prevent opportunities for the development of rent-seeking coalitions between populist and bankers tend to have less stable banking system (i.e., more crisis prone) and tend to provide less abundant credit. On the contrary, democracies with strong institutions that prevent rent-seeking tend to have stable banking system that provides higher levels of credit.

\section{BANKING Crises}

Financial crisis has very serious and lasting consequences: Banking collapses impact borrowers and can make credit more scarce, thus forcing businesses to cut back on investment and possibly reduce their workforce; individuals may also have to hold back on purchases and reduce their consumption; and they often lead to bailouts in which taxpayers have to pay to rescue the banks. As a result, unemployment increases, economic growth collapses, deficits and debt spiral, and currencies crash. Often, they also lead to political crises, as governments collapse. Reinhart and 
Rogoff (2009) have looked carefully at the consequences of financial crises. According to their seminal study, stock prices fall by more than $50 \%$ on average over more than three years; real estate markets fall by $35 \%$ over six years; economic output declines on average $9 \%$ over two years; and unemployment rises by $7 \%$ over more than four years (Reinhart and Rogoff 2009, p. 466). Moreover, financial crises also have serious political consequences on domestic politics, political stability, and governance survival: In Spain, for instance, the Socialist government that was in power at the time of the crisis was voted out in 2011, and subsequent elections have led to the collapse of the two-party system and increasing fragmentation of the party system, which has made the formation of governments far more difficult, and consequently, the country has had 4 general elections in 4 years (between 2015 and 2019). Finally, they can also lead to domestic or international conflict, as it happened with the European Union (EU) during the 2008 Euro crisis. Therefore, it is crucially important to explain why crises occur.

Yet, financial crises have become an unfortunate recurrent fact of life, and no country seems immune. Following the collapse of the Bretton Woods system in 1971, one of the most consequential economic developments of the world economy has been the globalization of finance. According to the Organization for Economic Cooperation and Development (OECD), gross cross-border capital flows rose from about 5\% of world GDP in the mid-1990s to about $20 \%$ in 2007, or about three times faster than world trade flows. While there have been many befits from this growth (e.g., in economic growth, investment, efficiency, or living standards), it has also led to increasing number of financial crises. According to the World Bank's Global Financial Development Database between 1976 and 2011, there have been 131 crisis years for OECD countries. During that period, only 3 countries, Australia, Canada, and New Zealand, have not experienced a systemic banking crisis. And Spain is one of the OECD countries with the highest number of crisis (Fig. 1.1).

However, the World Bank's classification is considered restrictive because it only measures systemic crises that result in multiple bank failures, or a systemic pattern of distress across a large number of financial institutions, and thus does not account for all episodes of financial in stability (see Copelovitch and Singer 2020, pp. 25-28). For this reason, scholars also use the classification of banking crises developed by Reinhart and Rogoff (2011), which is broader as they consider two types of events: 


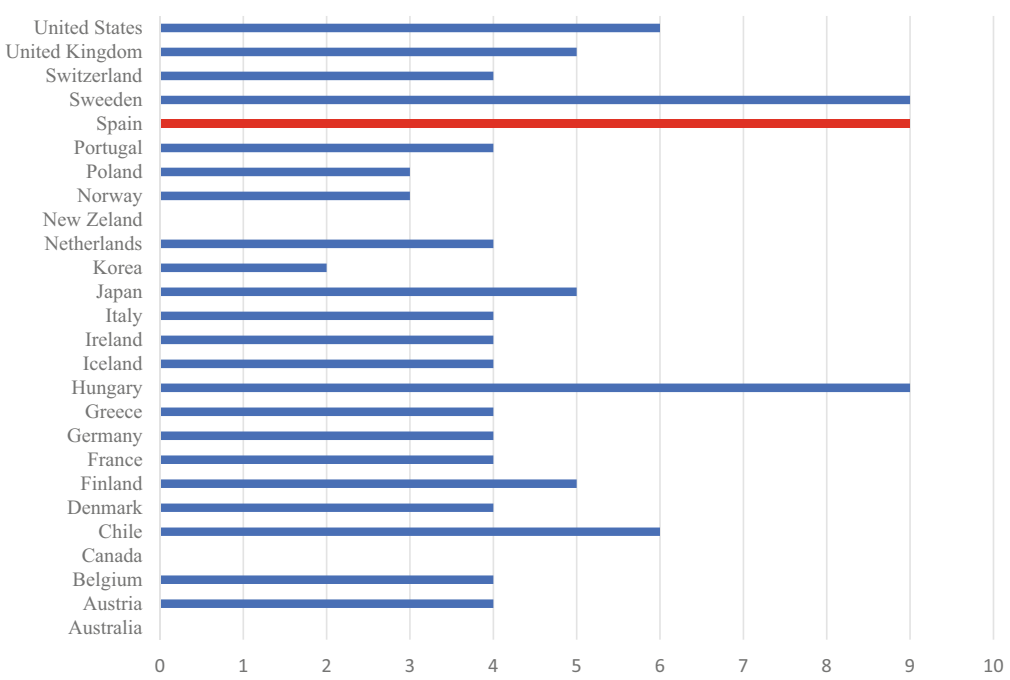

Fig. 1.1 Number of systemic banking crises, World Bank classification, OECD, 1976-2011 (Source World Bank, Global Financial Development Database. From Copelovitch and Singer [2020, p. 26])

"bank runs that lead to the closure, merging, or takeover by the public sector of one or more financial institutions," or "if there are no runs, the closure, merging, or takeover, or large scale governance assistance of an important financial institution (or group of institutions), that marks the start of a string of similar outcomes for other financial institutions" (Reinhart and Rogoff 2011, p. 1680). Under this classification, Spain also stands out for the number of banking crises (see Fig. 1.2).

While the focus of this book will be on banks ${ }^{3}$ and banking crises defined as either "systemic insolvency crises or systemic illiquidity crises" (Calomiris and Haber 2014, p. 5), when looking at the more recent performance of the Spanish banking system, it is very important to

3 The focus is on chartered banks rather than financial markets because in Spain (as in many other countries) banks have been, by far, the main sources of credit and access to capital. Financial markets are sustained and created by banks. For this reason, I use the terms 'financial system' and 'banking system' indistinctly in the book. 


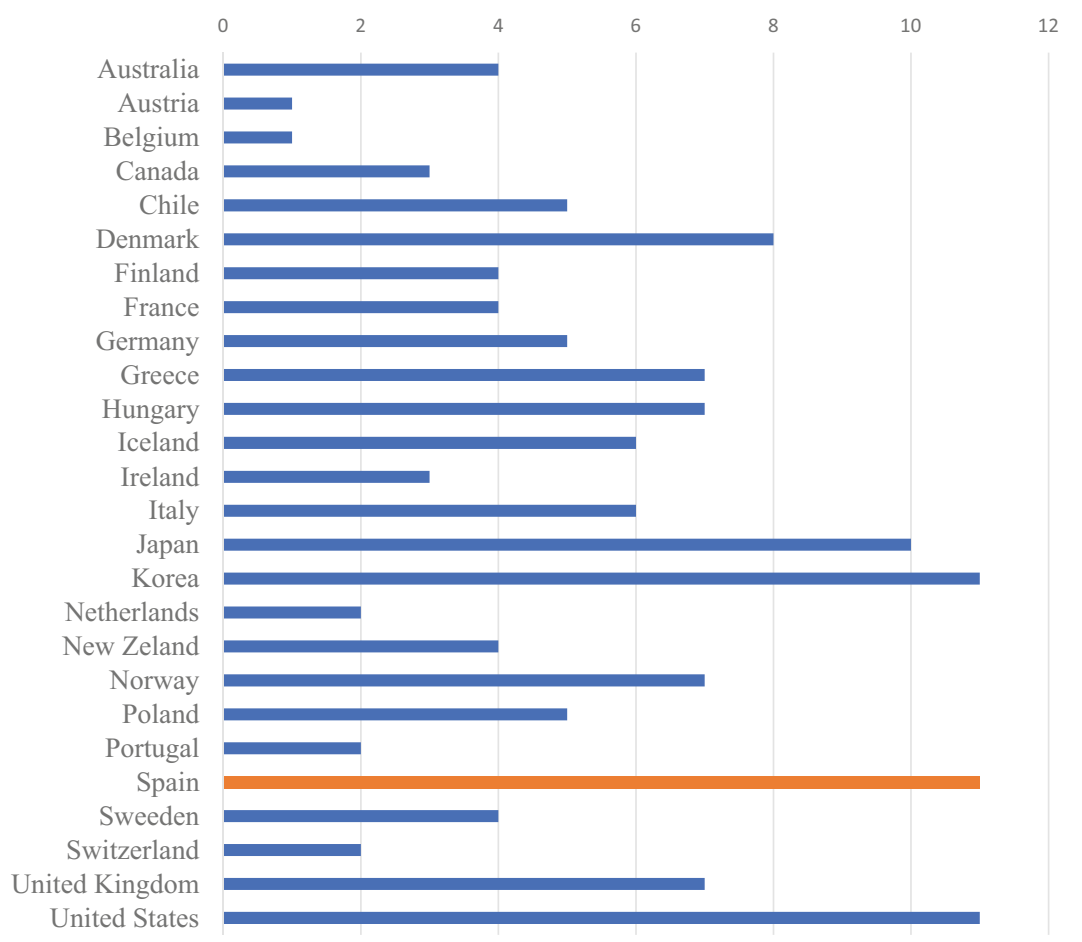

Fig. 1.2 Total banking crises (Reinhart and Rogoff classification). OECD, 1976-2009 (Source Allen and Rogoff 2011. From Copelovitch and Singer [2020, p. 27])

distinguish between the large banks and the cajas (savings and loans): The large banks performed relatively well while the cajas suffered from a somewhat traditional financial crisis. According to their argument, these crises occur when banking systems are vulnerable by virtue of the way in which they have been constructed (they are "fragile by design"). An analysis of banking crises shows that they typically take place either when banks have exposed themselves through high risks in their lending and investment, or when they have inadequate capital balance to absorb losses. Examining the case of Spain, this book confirms that such crises happen as a result of political choices, and that banks' crises reflect the structure of Spain's political institutions. 
This book seeks to explain why banking crises occur, focusing on the particular case of Spain, a country with a long tradition of banking crises. It seeks to delve into the discussion of why some countries are more prone to banking crises than others. It is different from other research that has examined the consequences of banking crises. It rather looks at the political factors that shape the configuration of banking systems, and attempts to isolate the political and structural factors that lead to crises. The variation in the market structure of banking systems is rooted in policy decisions and political bargains, many of which took place decades ago. The book focuses largely on the structure of the Spanish banking sector and the rules for allocating credit as the key explanation for banking instability in Spain. Hence, it analyzes the political coalitions that formed around particular configurations of banks, and it examines the incentives that lead banks to take on too much risk, which can take many forms. In Spain, as we will see, in the years prior to the 2008 global financial crisis in order to increase their profitability and market share, banks and cajas extended increasing amounts of credits to real estate developers and mortgage seekers, many of them with shaky or little credit histories and ultimately many of them required a massive bailout.

\section{The Economic Crisis in Spain}

The most recent banking crisis took place in the midst of one of the worst economic recessions in Spanish modern history (prior to COVID19). Indeed, the financial and the economic crises were so intertwined that is impossible to explain one without the other. Between 1996 and 2007, the Spanish economy was one of the fastest growing and the most successful economies in Europe. High levels of immigration, low interest rates, and the liberalization and modernization of the Spanish economy all contributed to this spectacular performance. This success, however, came to a halt in 2008, and in the winter of 2013, Spain was still suffering the effects of a very painful economic crisis.

As we will examine in Chapter 4, the great recession that began in 2008 has been blamed on global capital imbalances, inadequate central bank policies, greed, the failure of institutions, faulty risk assessment models, or the pervasive belief that 'this time was different,' that we had found the cure against the business cycle, and that housing prices would go on 
rising forever. However, while the global economic crisis has been a significant contributing factor in this downturn, this book shows that domestic factors largely help account for Spain's current economic problems.

The crisis in Spain took place in the context of two larger transformations. First, a socioeconomic transformation was driven by globalization (with the downward pressure that it has been exerting on wages), as well as the introduction of new technologies (with its impact on the labor market). Changing family structures, the decline of unions, the erosion of civil society, and educational gaps also impacted the socioeconomic fabric of the country. In addition, the economic crisis took place in the context of the unraveling of the national fabric. After decades of authoritarianism, the democratic transition of the late 1970s that culminated with the 1978 Constitution seemed to settle many of the divisions that had torn the country for centuries. The crisis, however, exposed the fragility of that settlement and battered institutions, political parties, the establishment, and national elites.

Indeed, the crisis had an earth-shattering effect in Spain at all levels: economic, political, institutional, and social. There have been different interpretations of the causes and culprits for the crisis. Most of the analyses on the economic crisis in Spain have concerned themselves with phenomena like mismanaged banks, excessive debts, the bubble in the real estate sector, or the loss of competitiveness (Royo 2013; Ortega and Pascual-Ramsay 2013; Quaglia and Royo 2015; Molinas 2013; Barrón 2012). Others have sought to explain the crisis as a by-product of globalization and/or European Monetary Union (EMU) integration because it eliminated exchange rate risks in a way in which investors in the southern countries accepted lower yields (Bermeo and Pontusson 2012; Kahler and Lake 2013; Armigeon and Baccaro 2012; Cameron 2012). This led to massive capital inflows toward the periphery that fuelled booms that turned into bubbles (in the case of Spain, particularly in the real estate sector), causing massive current account deficits. When the global financial crisis hit these countries, the bubble burst and investors refused to continue financing these deficits, which exposed these uncompetitive economies.

By focusing on a particular dimension of the crisis, the financial crisis, this book seeks to contribute to the debate about the causes of the crisis in Spain and seeks to complement those analyses (Royo 2013). It moves 
beyond the above explanations and seeks to focus in particular on the crisis of the Spanish financial sector. In particular, it focuses on the interplay between politics and banking.

\section{Overview of THE Book}

This book seeks to explain why the Spanish banking system has been historically so unstable, 'fragile,' and crises prone. It focuses on the intertwined connection between politics and banking in Spain, and it looks at the historical relationship between the economic power of Spain's largest financial institutions and the political power of successive Spanish governments. Building on the approach developed by Calomiris and Haber (2014), the book analyzes the coalitions, institutions, and regulations that have shaped banking in Spain. It shows how, through strategic bargains with successive governments and central bankers, large Spanish banks came to dominate the Spanish economy and how they retained their power even as the political system changed dramatically. Indeed, banks in Spain obtained regulatory concessions and privileges from governments in exchange for providing funding and channeling credit to politically popular causes. This led to a rent-seeking system in which politicians and bankers shared the spoils extracted from other sectors of society.

Furthermore, this historical analysis will help contextualize the changes in Spain's national financial system (NFS) and the extent to which it was affected by the international financial crisis of the mid-2000s. It also addresses the following question: What factors explain the way in which the Spanish financial system has been affected by the crisis and has reacted to it? In Spain, banking exposure to wholesale markets has increased significantly over the last decade and, therefore, has become "marketbased banking," with significant implications for the character of credit provision and the nature of the Spanish NFS. The lower reliance on bank lending proved to be beneficial at the beginning of the crisis. While most market-based systems faced further problems in the wake of the Lehman Brothers collapse, Spanish banks performed relatively well. However, the crisis eventually had a major impact, once more "traditional" problems with government debt and lending emerged. This book analyzes this reversal and explains its causes.

Prior to the crisis, Spanish regulators placed emphasis upon preexisting regulatory and supervisory frameworks, which initially shielded 
the Spanish financial system from the direct effects of the global financial crisis. This contributed to their initial positive performance compared with their European counterparts. However, as in Ireland, the collapse of the real estate markets eventually led to a traditional banking crisis fueled by turbocharged lending on the liability side of the Spanish bank's balance sheets. The global financial crisis and the subsequent credit crunch had a simultaneous effect: On the one hand, it reduced banks' ability to borrow and therefore to continue lending, thus leading to the collapse of the real estate sector; on the other, the property collapse contributed to reduce banks' ability to borrow. In order to explain the recent Spanish financial crisis, this book also focuses on the following factors: first, the regulatory framework; second, the institutional features of the banking system, including the role of the Bank of Spain (BoS); and third, the impact of macroeconomic developments, notably the real estate bubble. This book argues that the outcome is historical and contingent: There have been other causal independent variables of Spanish political and economic life that can be wielded to explain the crises.

Moreover, the Spanish banking system has not only been crisis prone, but it also has a troubling record of providing relatively small amounts of credit to business enterprises. While the main focus of the book will be on banking crises, it also examines another weakness of the Spanish banking system, namely its traditional inability system to provide enough credit relative to the size of the country's economy, and argues that this shortcoming is also the result of political choices (for comparative data, see Calomiris and Haber 2014, pp. 7-8). Not surprisingly, Spanish Small and Medium Enterprises (SMEs) often complained that banks were indifferent to their credit needs and not disposed to lend them money. ${ }^{4}$ Fishman (2010) highlights that the average annual rate of increase in credits to the economy during the period 1990-1998 was a mere $8.77 \%$ in Spain (as a point of contrast, it reached more than twice in Portugal-18.41\%). And as a result small Spanish manufacturing firms were being forced to finance their growth and development largely through their own internal resources: The internal funds ratio for small manufacturing firms in the

\footnotetext{
${ }^{4}$ According to Fishman, such concerns from small businesses about the availability of credit had been voiced prior to the recent crisis. For a sample of representative press reports based on a survey of small businesses Fishman references, El Pais, February 5, 2009, p. 17; Público, February 5, 2009, p. 3; and La Vanguardia, February 5, 2009, pp. 50-51.
} 
Table 1.1 Financing forms' initiatives in spain in the 1990s

\begin{tabular}{lcccc}
\hline & $\begin{array}{c}\text { Average annual } \\
\text { credit increase } \\
1990-1998^{a}\end{array}$ & $\begin{array}{c}\text { Internal funds } \\
\text { ratio }\end{array}$ & $\begin{array}{c}\text { New equity } \\
\text { ratio }^{c}\end{array}$ & $\begin{array}{c}\text { Long-term debt } \\
1997^{d}\end{array}$ \\
\hline Spain & $8.77 \%$ & $67.2 \%$ & $7.3 \%$ & $10.0 \%$ \\
EU median & $\mathrm{n} / \mathrm{a}$ & $\mathrm{e}^{2} 40.9 \%$ & $\mathrm{e}^{2} 2.8 \%$ & $11.7 \%$ \\
\hline
\end{tabular}

Source Fishman (2010, Table 5)

a Data reflect annual average for 1990-1998; Source OECD Historical Statistics 1970-1999 (2000, p. 92)

${ }^{b}$ Data refer to sources and application of funds for small manufacturing firms 1996-1997; Data from: Enterprises in Europe, Sixth Report, Eurostat/European Commissions (2001, p. 161)

${ }^{\mathrm{c}}$ Ibid

${ }^{\mathrm{d}}$ Data refer to long-term debt ratio as percent of total assets in small manufacturing firms; Source Ibid., p. 158

${ }^{\mathrm{e}} \mathrm{EU}$ data are based on figures from Austria, France, Germany, Italy, Portugal, and Spain, for these two measures

late 1990 s stood at $67.2 \%$ in Spain (vs. $21.2 \%$ in Portugal). Table 1.1 shows aggregate-level data on credits and financing for firms.

Fishman also notes that comparatively, lower access to funding also had an impact on innovation expenditures in Spain during the 1990s, a factor that hindered productivity growth, as noted in Chapter 4. For instance, innovation expenditures as a percentage of total "Turnover" between 1996 and 1997 were only 1\% by Spanish manufacturing firms vs. 2.5\% average in the EU-15, and the average annual increase in gross fixedcapital formation between 1989 and 1999 was $2.8 \%$ vs $2.1 \%$ in the EU15. This was aggravated by the fact that Spanish policy-makers preferred to use the EU funds for other purposes such as infrastructural improvements, and the Spanish state's contribution to gross domestic capital formation was also concentrated in public infrastructure (Fishman 2010).

The modern roots of this shortcoming are in the legacies of the authoritarian regime (Fishman 2010). According to Calomiris and Haber (2014, p. 47), under such regimes returns to equity holders are high, loans to insider firms are subsidized, governments and banks insiders extract significant rents, and periodic fiscal firms result in expropriations. Banks in autocratic regimes tend to allocate credit to insiders (which leads to what they call a "rent-distribution system"), and depositors are reluctant to put much of their liquid wealth into the banking system because they earn less than they would through other investments. This leads to a system of underdeveloped banks, a crony banking system that allocates credit 
narrowly and leads to scarce credit, which is self-reinforcing because it largely lacks the institutions that enforce contract rights: For instance, these countries and banks tend to lack adequate credit analysis, efficient property and commercial registers, and reporting services (they develop them when they have to make loans to unrelated parties and when they need to be able to sanction debtors for non-payments). In such autocratic systems, banks are less willing to incur the costs to develop these institutions/resources that can facilitate arm's-length lending, and may even oppose them if they would erode their rents and/or facilitate such lending by others. Finally, these systems tend also to be unstable and lead to frequent crises because of the lack of constraints on the autocrat's authority (which may give him/her incentives to expropriate the banks when he/she has financial needs) and the tendency on the part of bank insiders to lend to their nonfinancial enterprises and rescue them, particularly during economic crises.

Indeed, Spain was characterized by comparatively high costs of credit and high return on financial assets throughout the 1980s and 1990s (see Pérez 1997, pp. 12-18). According to the European Commission's $\mathrm{BACH}$ project, the average cost of investment finance for Spanish firms was high compared to other countries. Prior to the full establishment of the Single Market and the EMU, and in the absence of perfect capital mobility across borders, these higher costs were attributed to the comparatively scarcity of capital in Spain. But the problem was even deeper. Investment costs not only were higher but they were also unresponsive to economic conditions (even when macroeconomic variables like public debt, inflation, or public deficit improved, which they did throughout the 1980s and 1990s); the costs were still high; and the cost of investment finance was also high in relation to the rate of return (ROR) on investment: Spanish firms experienced a very negative leverage effect, ${ }^{5}$ which meant that Spanish firms were decreasing the profitability of their equity when they borrowed to invest in productive capacity, job creation, or technological innovation, and therefore, it was a strong disincentive for investment. In Spain, the costs of finance were largely determined by the rates charged by banks on credit, because banking loans were the principal source of external funding for Spanish firms.

\footnotetext{
${ }^{5}$ It measures difference between the average rate of return (ROR) of firms and the costs of external financing: when positive firms can increase their ROR by borrowing, but when negative it would decrease the profitability of their equity.
} 
The comparatively higher costs of investment finance behind the strong negative leverage effect in Spain have also been attributed to macroeconomic policies, and particularly the high levels of public spending and public deficits, because monetary policy had to compensate for the lack of financial restraint, which had a "crowding-out" effect (see GonzálezPáramo et al. in Pérez p. 17, footnote 14). Pérez (1997) challenges this interpretation and shows that fiscal deficits had a structural component, that they were not comparatively high, and that there was also a limited degree of variation in credit rates: When deficits rose, the level of credit rates barely changed.

Other scholars (Torrero 1989) have attributed banks' capacity to charge higher interest rates in the 1980s to the lack of leverage of Spanish firms who were desperate for credit at a time of crisis and high indebtedness. When economic conditions improved in the second half of the 1980s, they decreased their borrowing and increased their self-financing. Yet, banks were still able to continue raising interest rates (and profit margins) by focusing on creditors who did not face external competition and could pass the higher costs to their consumers (i.e., utilities and service ventures). However, Pérez (1997, p. 20) shows convincingly that the reason for this behavior was "the existence of an oligopolistic financial structure" that allowed Spanish banks to increase their costs and earnings in the middle of a severe recession, which had a significant impact on the high financial costs borne by Spanish firms in the 1980s. This oligopolistic structure persisted for over a decade, despite a process of financial liberalization undertook by the financial system. Pérez (1997, pp. 21-22) shows how the credit deregulation process that started in the late $1970 \mathrm{~s}$ was not accompanied by the introduction of any significant competition into the Spanish financial market, even when foreign banks and domestic savings and loans were allowed to expand their activities, because they still faced operational constraints during the 1980s that prevented them from exerting downward pressure on credit rates.

Not surprisingly firms responded in the late 1980s by reducing their recourse to financing. An under-bank situation has significant social and economic costs for any country, as several studies have shown that lower levels of financial development impact physical capital accumulation, economic growth, technological progress, job creation, and social mobility (i.e., King and Levine 1993; Taylor 1998). They also impact the investment behavior of firms. As a result, countries suffer lost investment opportunities and competitive disadvantages: Potential entrepreneurs and 
investors are starved for credit, while bank cronies have plenty of access to funds. In the case of Spain, the high costs of capital shifted the burden of adjustment in the 1980s toward Spanish firms and intensified a bias against investment in productive capacity. The book shows that the scarcity of credit (or under-banking) has also been a result of the structure of Spain's political institutions.

In addition, this book shows that banks' crises happen as a result of political choices, and that they reflect the structure of Spain's political institutions. It argues that a fundamental reason for both the 2008 financial crisis and the economic crisis is rooted in the process of institutional degeneration that preceded the crisis (see Ferguson 2013). It seeks to explore the consequences that the institutional degradation has brought to the Spanish economy. The World Bank's World Governance Indicators provide relatively detailed, survey data-based assessments of the operation of political systems. The database contains six variables: (1) control of corruption, (2) government effectiveness, (3) political stability and absence of violence, (4) regulatory quality, (5) rule of law, and (6) voice and accountability. Out of the six, three-(1), (5), and (6)-can be considered direct measures of democratic quality, whereas the other three-(2), (3), and (4) - can be rather seen as measures of government efficiency. In the Spanish case, all three democratic quality variables showed little improvement between 1996 and 2008, and the corruption one even deteriorated. Meanwhile, the three government efficiency variables-political stability and absence of violence, government effectiveness, and regulatory quality_also exhibited deterioration between 1996 and 2013 (see Fig. 1.3). Moreover, although Freedom House still scores Spain 4 out of 4 for an independent judiciary, it also highlights deficiencies in the country's safeguards against official corruption (scoring it 3 out of 4 ) and stresses that:

Although the courts have a solid record of investigating and prosecuting corruption cases, the system is often overburdened, and cases move slowly. For instance, among other high-profile proceedings during the year, in May 2018, after 10 years of investigation, the courts handed down convictions for 29 of the 37 people indicted over their alleged involvement in the illegal financing of the PP from 1999 to 2005 . The party itself was found to have benefited from the schemes and was ordered to pay a $€ 240,000$ $(\$ 280,000)$ fine. $^{6}$

${ }^{6}$ https://freedomhouse.org/country/spain/freedom-world/2019. 


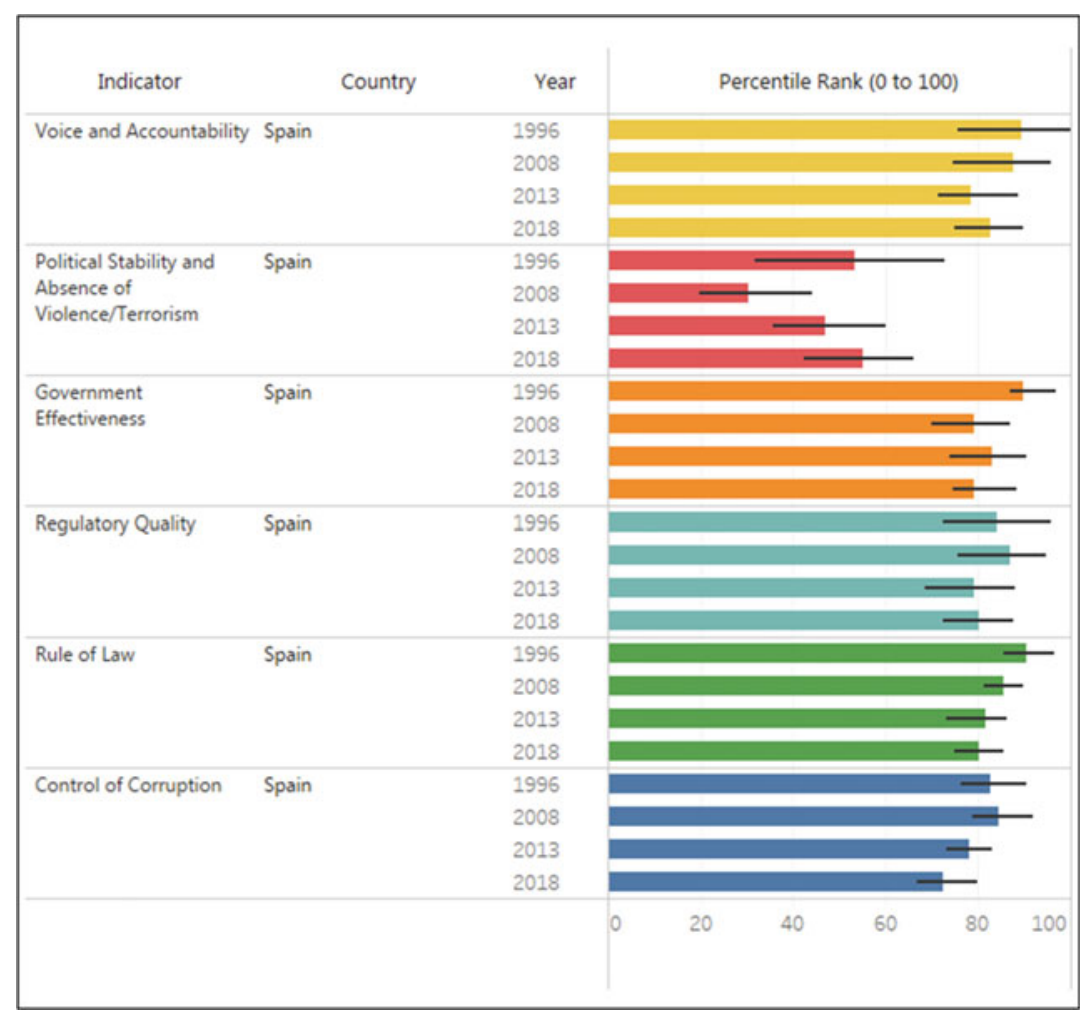

Fig. 1.3 Worldwide Governance Indicators (Source The Worldwide Governance Indicators. http://info.worldbank.org/governance/wgi/\#home)

This book argues that the process of institutional degeneration led to a Spanish version of crony capitalism characterized by the misgovernment of the public; an outdated and inadequate policy-making process; an inefficient state; and an often corrupt and inefficient political class. Mismanaged banks, excessive debts, bubbles in the real estate sector, or competitiveness losses are all symptoms of an institutional malaise that intensified in the years prior to the crisis. Indeed, we cannot understand the bubble in the real estate sector, the loss of competitiveness, or the financial crisis without referencing the institutional divergence in the rule of law between Spain and the EU core. As analyzed in great detail in 
Chapter 7, the real estate bubble, the competitiveness divergence, and the financial crisis are all rooted on the rule of law divergence. Moreover, it was this institutional divergence that made it difficult to implement the reforms that EMU demanded (and that the financial bailout ended up imposing in the country). Chapter 7 seeks to examine the causes of Spain's 'stationary state' and argues that they are in large part the result of 'laws and institutions.' They are the problem, and the economic crisis was a symptom of the institutional degeneration (Ferguson 2013, pp. 8-10).

Therefore, this research also builds on and develops further the institutional approach by Ferguson (2013), and Acemoglu and Robinson (2012), identifying the distinctive institutional features that underline countries' economic success (or lack thereof). It shows that the economic success spurred by the country's modernization and European Union membership was not sustained because the governments (at all levels, local, regional, and national) became less accountable and responsive to citizens. In terms of causal mechanisms between institutional degradation and economic crisis, it shows (following Acemoglu and Robinson's terminology) that institutions across the country became more 'extractive' and concentrated power and opportunity in the hands of only a few. Indeed, political and economic institutions came short in empowering and protecting the full potential of Spanish citizens to innovate, develop, and invest. They did not foster the degree of 'creative destruction' that is vital for innovation and sustainable growth, and instead, they promoted an unsustainable model based on a real estate bubble. Finally, institutional deterioration made it difficult to implement the economic reforms required as members of a monetary union. Political and economic institutions resisted reforms because they would jeopardize the existence of the extractive rent-seeking mechanisms that became the main source of rent for the economic and political elites that controlled them.

In sum, the book seeks to examine the structure of the Spanish financial system with particular emphasis on the last two decades (1994-2014) to answer the question: Why has Spain not been able to construct a banking system that avoids banking crises? In doing so, it analyzes in particular the basis of the financial system's apparent success during the 1997-2007 period, and then, it examines the imbalances that made that success unsustainable, and ultimately led to the financial bailout. The book also looks at its consequences of the financial crisis. Finally, based on the analysis of 
the Spanish experience (both within the EU/EMU and during the crisis), it draws some lessons that would be of interest from a normative standpoint.

This book contends that the performance of the Spanish financial system was largely driven by institutional and political factors. It examines the rules and institutions that have shaped Spanish banking, focusing, in particular, on the role that politicians and governments (Calomiris and Hager's "banking games") have played. It offers an alternative to stateand market-driven conceptions of financial regulation and reform, and examines the accommodation between private bankers, politicians, and central bankers in Spain. It examines the political coalitions that have shaped the structure of the Spanish financial system, and the consequences that these trade-offs had during the recent economic and financial crisis.

In addition, the book also examines the development of the sovereign debt crisis in Spain. Initially, it had a 'good' banking crisis and it was only hit by the sovereign debt crisis as late as mid-2011. Spanish banks suffered a traditional banking crisis from late 2010 onward. As the crisis intensified, Spain's banking sector could not escape its dramatic effects. Deteriorating economic conditions, the implosion of the real estate market, the dependence on wholesale funding, weaknesses in the regulatory framework, and the role of the BoS all help to explain this reversal. In the end, the Spanish government resorted to European Union (EU) financial aid in order to recapitalize its banks. The book argues that the distinctive features of bank business models and of national banking systems in Spain have considerable analytical leverage in explaining the different scenarios of the crises. This 'bank-based' analysis contributes to the flourishing literature that examines changes in banking with a view to account for the differentiated impact of the global banking crisis first and the sovereign debt crisis in the Eurozone later.

The book also addresses the impact of European integration on a Southern European/peripheral economy. The recent experience of the country shows that EU and EMU membership have not led to the implementation of the structural reforms necessary to address the country's economic weaknesses (i.e., dependency on the constructions sector and the erosion in competitiveness). On the contrary, the book will make the case that EMU contributed to the economic boom, which was fueled by consumption and record-low interest rates, thus facilitating the postponement of necessary economic reforms (Royo 2013). Indeed, the 
Spanish experience shows that the process of economic reforms has to be a domestic process led by domestic actors willing to carry them out.

Finally, the book explores one of the core questions facing the new Europe, namely the sustainability of the EMU in the context of sharp differences in economic performance and levels of competitiveness. Spain shows the pitfalls of monetary integration for less competitive economies, used previously to high inflation and high interest rates. These countries are likely to experience an explosion in consumer spending and borrowing, because lower interest rates and the loosening of credit will likely lead to a credit boom. This development resulted in further losses in external competitiveness, together with a shift from the tradable to the non-tradable sector of the economy, which had a negative impact on productivity. How can these issues be addressed to make EMU sustainable?

\section{What Is Unique About This Book?}

First, the focus is on Spain. There are very few books published in English that examine the Spanish financial sector, and almost none that examine the crises proneness of the sector from a historical perspective looking at institutional and political factors. Second, the book examines the distinctive performance of Spain's financial sector during the recent 2008 global financial crisis. Indeed, initially during the first years of the global financial crisis, one of the few unexpected surprises was the positive performance of the Spanish financial sector. Contrary to their counterparts all over the world, at the beginning of the crisis, Spanish banks appeared to have escaped the direct effects of the global financial crisis, and it is important to understand why. There is consensus that the stern regulations of the BoS and its countercyclical provisions played a key role in this outcome. It also made it so expensive for financial institutions to establish off-balance sheet vehicles, which had sunk banks elsewhere, that Spanish banks stayed away from such toxic assets. However, the deepening economic crisis would eventually catch up with Spanish banks and cajas and Spain was ultimately forced to request a financial bailout. This reversal needs to be explained.

Furthermore, the book offers an alternative to state- and market-driven conceptions of financial regulation and reform, and examines the accommodation between private bankers, governments, and central bankers in Spain. Indeed, by looking at the latest crisis from a historical perspective and examining the historical fragility of the Spanish banking system, 
the book offers an alternative explanation to the recent financial crisis in Spain. A lot of the focus in explaining the crisis has been on the corrupt business practices and the greed of bankers (particularly in the Cajas de Ahorro). Others have focused on the inherent characteristics of banks that make them vulnerable to panics. Following Calomiris and Haber (2014), this book focuses on the politics of banking and it shows that the crisis was a result of human agency. The structure of Spain's financial system was the product of the country's culture, history, and the political system, yet the crisis has been the outcome of domestic political conditions and domestic political bargains between competing (and sometimes cooperating) interests mediated in the political arena. It shows how EMU and cheap wholesale financing encouraged bankers (particularly in the cajas) to engage in aggressive lending to the real state sector. Despite the BoS's countercyclical regulatory framework, the capital requirements proved insufficient and banks were able to rely heavily on borrowing. Ultimately, that proved to be fatal for many of them.

The book also integrates the Spanish financial European integration experience and analyzes the effects of financial integration in (relatively) new democracies in Europe. The Spanish experience within the European Union (EU) and the EMU offers one of the few instances in which integration took place in an economic, political, and institutional context markedly different from that of the other European states. At the same time, the book evaluates the impact of EU/EMU accession on the Spanish economy and financial sector. While initially successful, EMU membership brought its own problems for the Spanish economy. The Spanish experience with EU/EMU integration illustrates the economic, social, institutional, and cultural challenges of this undertaking and will provide useful lessons for other countries. While integration has had very positive effects, the process of integration has also brought significant costs in terms of economic adjustment, loss of sovereignty, and cultural homogenization. Furthermore, EU/EMU integration does not guarantee success. Indeed, Spain suffered a severe economic downturn between 2008 and 2013 and experienced serious budgetary and fiscal problems that hampered economic growth and are likely to impact the Spanish economy and financial sector for the foreseeable future. The financial sector is a crucial actor to account for these challenges.

Finally, at a time in which there are increasing doubts about the future of EMU, this book sheds light on the impact of monetary integration 
on a 'peripheral' economy, with a particular focus on the financial system. It shows that in the case of Spain, EMU membership contributed to prevent capital flight and helped to avoid a repetition of the attacks on the peseta. Without the Euro, the huge trade deficit that countries like Spain experienced prior to the 2008 crisis would have led to massive capital flight, a devaluation of the peseta, an inflationary spiral, increases in interest rates and the risk premium (with the associated impact on the cost of the debt), and the implementation of more restrictive monetary and fiscal policies. However, the Spanish experience also shows the pitfalls of monetary integration for less competitive economies with an inflationary history. These countries are likely to experience an explosion in consumer spending and borrowing, because lower interest rates and the loosening of credit will likely lead to a credit boom, driven by potentially over-optimistic expectations of future permanent income, which in turn may increase housing demand and household indebtedness; and lead to overestimations of potential output and to expansionary fiscal policies. The boom also led to higher wage increases, caused by the tightening of the labor market, higher inflation, and losses in external competitiveness, together with a shift from the tradable to the non-tradable sector of the economy, which had a negative impact on productivity. In the end, the insufficient responsiveness of prices and wages, which did not adjust smoothly across sectors, led to accumulated competitiveness losses and large external imbalances. In this regard, the book stresses the need to implement supply-side reforms to bring labor costs down, through wage restraint, payroll tax cuts, and productivity increases, in order to make the country's economy more competitive.

\section{Literature REVIEW}

Banking crises theories have focused on three main factors: the structure of banks (they focus on liquidity risks arising from the mismatch between illiquid and long-term loans a liquid and short-term liabilities); interbank connections (they focus on the problem of externalities, when banks fail to take into account the spillover effects created by their integration in a banking system); and human nature (human errors motivated by excessive optimism or excessive fear). Calomiris and Haber (2014), however, show that the problem with these theories is that they fail to "explain why banking crises are equally likely across all countries and all of recent history" (pp. 480-81). According to them, the problems that these theories 
identify are not sufficient conditions for causing banking crises, and the crucial factor that determines whether the problems identified by these theories will result in a banking crisis is political: the choices made by politicians, often motivated by their short-term interests. These political choices will determine the degree of safety nets and prudential regulation, which in turn will influence banks' decisions. In addition, the degree of generosity of the safety net, and/or the level of appropriate prudential regulation, will influence whether banks are more or less cautious in how they manage their risk. For instance, if the safety net is too generous, and/or prudential regulation is insufficient, it is more likely that banks will be less cautious in their management of risk and vice versa. Finally, politics can also lead to shocks (from war to political transitions) that will influence approaches to bank risk. In the end, the structure of the banking system, and its susceptibility to adverse shocks, is an outcome of politics and political outcomes, which shape the rules under which banks operate and determine the context to which they are subject (2014, pp. 483-84).

Furthermore, the economic literature has paid considerable attention to the economic factors associated with sovereign debt crises. One of the most extensive studies of financial crises highlights a strong causal link between banking crises and sovereign defaults in developed and developing countries (Reinhart and Rogoff 2009). Kaminsky and Reinhart (1999) also highlight the link between banking crises and balance of payment crises (the so-called twin crises). They found that financial liberalization often precedes banking crises, and also that problems in the banking sector typically precede a currency crisis-in other words, the currency crisis often deepens the banking crisis, activating a vicious spiral. According to these analyses, economic crises occur as the economy enters a recession, following a prolonged boom in economic activity fueled by credit, capital inflows, and accompanied by an overvalued currency. These accounts, written by economists, draw our attention to banking crises and balance of payments crises as the precursors of sovereign debt crises. The accounts are, however, devoid of political analysis and do not explain the initial causes of banking crises and balance of payment crises.

In the political economy literature, several complementary explanations account for the occurrence of sovereign debt crises, mainly in developing countries. These explanations can be articulated either at the international level, whereby the focus is on external factors that caused the crisis, or alternatively at the national level, whereby the focus is on the domestic factors that caused the crisis (for a similar macro-meso distinction, see 
Germain 2012). At the international level, different authors have pointed out a variety of factors that can fuel sovereign debt crises, namely the impact of capital liberalization (Stiglitz 2000); the activity of bond markets (Mosley 2003) and financial innovation, especially financialization (Hardie 2011); the spread of neoliberal ideas (Major 2012); and the lack of a proper hegemon in the international system (Kindleberger 1973) more recently in the European Union (Mabbet and Schelke 2015). Finally, Skocpol (1979) seminal comparative work on social revolutions argued for structural analysis and emphasized the effects of transnational and world-historical contexts upon domestic political conflicts.

While some elements of an economic and/or financial crisis can certainly be explained by international factors-such as financial liberalization-these factors are basically the same for all countries, especially within the relatively homogenous regional block of the Euro area. Hence, they are not well suited to explain differences in the outcomes of the sovereign debt crises across countries. These background factors fueled the sovereign debt crisis, but domestic factors better explain different dynamics of the crisis across countries (see Jabko and Massoc 2012; Haggard and Mo 2000).

This book is also situated within the broader literature about the comparative political economy of Spain's financial system. Some scholars have sought to place the politics of financial reform in Spain in a historical context. Sofía Pérez (1997) and Arvid Lukauskas (1997) have already challenged the widespread assumption that international market forces alone explain domestic financial reforms in Spain. Both claim that in that country domestic politics played an even larger role than international pressures. Pérez contends that domestic elites, particularly a group of reformers within the central bank, seized on liberal economic arguments and developed new patterns of accommodation with private bankers to promote reforms. She emphasizes the oligopolistic nature of the sector, arguing that this system generated significant costs for Spanish firms outside the finance sector.

Lukauskas also examines the role of public officials in the evolution of financial regulation in Spain, but he is more favorable to the Spanish political class. He claims that they undertook financial liberalization, despite opposition from powerful groups, to achieve political goals; democratization gave them a strong incentive to improve economic performance through financial reform in order to compete for votes. He attributes 
their banking policies to an electorally based desire to secure economic outcomes, such as growth, pleasing the median voter.

More recently, in another seminal piece, Robert Fishman (2010) has also analyzed the economic consequences of Spain's banking system and has shown how that country's poor employment performance has also been rooted in the financial system. Fishman argues that the Spanish policy-makers' approach was molded by the country's path to democracy, which shaped the political handling of banking and of financing for SMEs.

In addition, this book is positioned within the Varieties of Capitalism (VoC) debate about liberal market economies and coordinated market economies (Hall and Soskice 2001). According to the VoC literature, Spain is characterized by strong strategic coordination in financial markets, but not so in the field of labor relations (Royo 2008). In this regard, some have claimed that Spain is moving toward the Anglo-Saxon model because the lack of articulation of the Spanish institutional model precludes the evolution toward a Coordinated Market Economy-CME (see Molina and Rhodes 2007). The analysis of the Spanish experience during the crisis confirms the thesis that coordination is a political process. It shows that institutional change is a political matter and how successful coordination depends not only on the organization of the social actors but on their interests and strategies. Indeed, in a context of structural changes, we have to examine the political settlements that motivate the economic actors, and we need to look at the evolving interests of capital and the structural and political constraints within which economic actors define and defend their interests (Royo 2000, 2008).

Furthermore, theoretically, the book builds on and develops further the literature on VoC, highlighting the bank bargains and the role of certain domestic political economy institutions in the development of the crisis. While financial capitalisms have converged toward deregulation as a result of the combined processes of globalization and European integration, this book shows that differences persist. Indeed, in the case of Spain, the crisis has led to extensive regulatory intervention that has served to reinforce the pre-existing model. Methodologically, it 'dissects' the sovereign debt crisis into three interconnected crises: the banking crisis, the fiscal crisis, and the balance of payment crisis, examining the 'anatomy' of each crisis paying particular attention to the interplay of domestic political economy institutions therein. 
According to the standard typology of the varieties of financial capitalism, NFSs can be divided into 'bank based' and 'market based' depending on the dominant sources of nonfinancial-company (NFC) finance (Zysman 1983). This literature focuses on national systems as governments and/or NFCs as agents of change. Indeed, the transformation of NFSs is largely seen in terms of the rise of shareholding capitalism and a move away from bank-financed capitalism-an analysis which points to the implications of the end of 'patient capital' for other elements of the national variety of capitalism. According to this view, banks are static, so any changes in their activities, and the implications of those changes, are largely neglected. In other words, it tends to overlook the important role of banking and banks and their contribution to change (Hardie and Howarth 2013). This book seeks to address this shortcoming by focusing on agency (the operation of Spanish banks) in order to explain changes in national financial (and specifically banking) systems during the global financial crisis (Quaglia and Royo 2015). Yet, while the focus is upon the activities of banks, it is also necessary to understand the institutional framework that has shaped banking activities in Spain.

Moreover, an obvious additional starting point to investigate the importance of national-level institutional factors in how the sovereign debt crisis played out is also the literature on VoC (for comprehensive analyses, see Amable 2003; Hancké et al. 2007; Hall and Soskice 2001; Schmidt 2002; for a review, see Jackson and Deeg 2008). These works have examined the main components of VoC, namely industrial relations institutions; education and training systems; corporate governance and systems of corporate financing; product markets; social protection systems and welfare states; and public intervention in the economy.

This literature has generally focused on the Anglo-Saxon and continental VoC, characterizing them, respectively, as 'liberal market economies' and 'coordinated market economies.' The Southern European countries have been overlooked or placed in a residual category of 'Southern European' or 'State-led' model of capitalism (Schmidt 2002; Della Sala 2004; Royo 2008). The literature on VoC is of limited utility in explaining the dynamics of the economic crisis in Spain, because it inaccurately predicts similar outcomes among countries with similar institutional frameworks.

For instance, in the academic literature, Italy and Spain are often grouped together in the same variety of 'Southern European' capitalism. Consequently, one could have expected similar outcomes from the crises in the two countries. However, Spain experienced a full-fledged sovereign 
debt crisis resorting to Euroarea financial assistance for its banks, whereas Italy did not. Indeed, Spain experienced a severe banking crisis including the bailout of a number of the country's banks which substantially increased the public deficit and debt. By contrast, Italian banks, with one exception, did not experience such significant losses and they needed no recapitalization by the government (Quaglia and Royo 2015). To be fair, this literature was not developed to explain sovereign debt crises, but rather to tease out institutional complementarities that can enhance or hinder the competitiveness of national economic systems in the world economy.

From a political economy standpoint, this book also challenges the interpretation according to which the responses of European countries to the pressures associated with globalization and the process of European integration are uniform. Contrary to this prediction, this book shows that in Spain globalization and European integration have promoted rather than undermining alternative domestic responses. While technological changes, capital market integration, and post-industrialization have affected the balance of power between governments and private actors and have triggered new political realignments, they have also influenced the interests and strategies of the actors and have led to new strategies and patterns of change. These developments have led to particular economic policies and preferences, but they have also precluded the implementation of alternative policy options, and they have often hindered the necessary reforms.

The literature on domestic political economy institutions and economic policies (e.g., Thelen 2004; Mahoney and Thelen 2009) is also of relevance for this research, in particular those works that have looked at the interaction between domestic and external factors in economic policy. Some authors have examined the effects of 'internationalization' and 'liberalization' on domestic political economy institutions, such as financial markets (Pérez 1997; Deeg and Luetz 2001; Thatcher 2007) and systems of corporate finance and governance (Deeg and Pérez 2000). Other authors have highlighted the role of the state and domestic political institutions in framing globalization (Weiss 2003), and more generally in political economy (Schmidt 2009). This book is grounded in the comparative historical analysis literature. It seeks to offer a historical grounded explanation of the 2008 economic crisis in Spain, and it is concerned with causal analysis (the causes of the economic crisis) while emphasizing processes over time. 
This book builds on these contributions and stresses the agency of domestic actors in shaping NFS change. It uses a comparative historical analysis approach to explain the financial crisis. This holistic analysis will contribute to a more complete understanding of the national varieties of financial capitalism.

Lastly, this book is also placed within the financial stability literature. A large body of literature has examined the impact of capital flows on financial crises. Many have concluded that global capital is the most likely culprit of banking crisis: Reinhart and Rogoff (2009) look at the historical pattern that connects capital inflows, large current account deficits, asset bubbles, excessive indebtedness, sovereign borrowing, and financial crises. Chinn and Frieden (2011) examine the causes of financial crisis, like the 1994 Mexican crisis, the 1997 Asian crisis, or the 2008 global financial crisis, and attribute to capital inflows the economic boom that fueled the financial exuberance that ultimately ends in a financial crisis. Portes (2009) emphasizes distortions in the allocation of capital as it is channeled through financial intermediaries and banking institutions. Schularick and Taylor (2012) analyze long-terms patterns of financial instability and find that the single most important determinant of banking crisis is domestic credit growth, and that capital inflows go hand in hand with credit booms. Other scholars, however, have found a weak link between capital inflows and domestic credit growth (Amri et al. 2016), while others have found a weak causal link between capital inflows and banking crises and no significant correlation between capital inflows and bank credit, showing that credit booms appear to be a separate channel of financial instability (Copelovitch and Singer 2020). They show that, while sustained capital inflows can be dangerous by linking current account deficits and large capital inflows to distortions in the allocation of capital, there are many cases (like Australia and New Zealand) in which large capital inflows, asset bubbles, and macroeconomic imbalances do not result in banking crises. Furthermore, capital does not always flow from surplus to deficit countries (e.g., the United States where two-thirds of capital inflows arrive from countries with which the United States does not run a large current account deficit) (pp. 185-86). These authors show, as we will see below, that larger capital inflows are associated with reduced bank capital levels only at high levels of market/ban ratio (p. 68). Finally, Caballero (2016) has also examined the association between capital inflows and banking crisis and found out that the impact is driven by debt flows and portfolio equity. 
Another stream of this literature led by Kindleberger and Minsky's classic financial stability model looks at the stages of financial crises. Their model can be summarized in five different stages: displacement, boom, overtrading, revulsion, and tranquility (see Kindleberger 1996; Minsky 1982a, b). According to this model, the crisis starts with an exogenous shock to the economic system that impacts profits and opportunities in at least one sector (displacement). Economic actors take advantage of this opportunity(ies), which lead to the second stage, a boom, that in turn increases the money supply. The economy accelerates, which leads to the third stage, overtrading, caused by over-borrowing, over-consumption, and/or over-investment. When some insiders try to capitalize from this boom and sell out to take their profits, it leads to the fourth stage, revulsion. At that stage, when economic actors realize that the market cannot continue growing, any shock can turn into a stampede. Finally, the last stage, tranquility, takes place when investors move to less liquid assets, trade is cut off, or a lender of last resort provides sufficient liquidity (Kindleberger 1996, p. 15). This model provides a systematic interpretation of the anatomy of the Spanish financial crisis. As we will see throughout the book, the stages of the model can be traced in five episodes of the turmoil: financial liberalization policies; credit growth; over-borrowing, over-consumption, and over-investment; financial distress and crisis; and financial rescue.

Furthermore, the financial stability literature also examines how we can achieve financial stability in a world of cross-border banking, and whether governments can still produce this public good at the national level in today's globalized financial markets. In this regard, the examination of the Spanish case confirms Schoenmaker's financial stability trilemma (2008, 2011). Schoenmaker examines the trade-off between financial integration and national financial autonomy and argues that financial stability, financial integration, and national financial policies are incompatible. Any two of the three objectives can be combined but not all three; one has to give. Spain tried to achieve all three and failed. In order to address this trilemma, Schoenmaker supports transferring powers for financial policies (regulation, supervision, and stability) further to the European level. This would imply a European-based system of financial supervision.

Avgouleas and Goodhart (2015) have analyzed bail-in processes that involve the participation of bank creditors in bearing the costs of restoring a failing bank to health as an alternative to the unpopular bailout 
approach. The bail-in tool involves replacing the implicit public guarantee with a system of private penalties. They show the benefits and the disadvantages of this approach. The analysis of the Spanish case confirms the downsides of the bail-in approach and shows how bail-in regimes do not eradicate the need for injection of public funds where there is a threat of systemic collapse because a number of banks (in the Spanish case cajas) simultaneously entered into difficulties.

The book is also situated in the literature on financial instability caused by defaults on mortgages. Goodhart et al. (2010) explore financial instability due to a housing crisis and defaults on mortgages. They build a model that shows how tight money reduces prices and quantities traded. While government support to banks in crises stabilizes the economy, when banks become risk-loving, a subsequent crisis becomes even more extreme. Their model helps account for the risk-seeking behavior of Spanish financial intermediaries in 2004-06 that ultimately led to the combined collapse of the housing and (nearly) financial markets. Jiménez et al. (2014) and Maddaloni and Peydró (2011) have also shown how low interest rates may lead to a search for higher yields, encouraging banks to soften their credit standards, thereby increasing both the volume and average riskiness of supplied loans; and Maddaloni and Peydró (2011) have found that lower overnight interest rates induce lowly capitalized banks to grant more loan applications to risky firms and "to commit larger loan volumes with fewer collateral requirements to these firms, yet with a higher ex post likelihood of default."

Moreover, Goodhart et al. (2012) look at regulatory design. They compare different potential financial externalities and examine how to regulate them. They recognize that "trying to lean against the wind to reduce the credit expansion and house prices in the boom via regulation is not easy" (p. 42) because the boom (as shown in the Spanish case) brings large increases in asset prices, and higher prices deliver higher capital gains to owners of the assets. At the same time, while these home price gains improve the equity of mortgage holders and lower the loan to value ratio on their mortgages, they also improve bank capital ratios because the mortgages are less risky and because the home price gains raise bank equity. All these effects show the difficulty during boom periods, as it happened in Spain before the crisis, of trying to impose higher loan to value requirements, to raise capital standards, or to lift margin requirements on repo loans enough to slow down credit expansion and try to reduce house price appreciation. These authors show that the most effective ways to 
address these issues are through dynamic provisioning rules and liquidity requirements that may help slow mortgage credit growth and thus lower the relative price of house prices. However, their model shows, as confirmed by the Spanish experience, that changes to capital rules, progress on revising other regulations such as liquidity, margin requirements, or time-varying provisioning rules, have a limited impact, as capital alone is unlikely to be sufficient to contain the problems arising during a crisis, as it happened in Spain.

Many studies have also examined how monetary policy drives bank risk-taking and have focused specifically on the overall failures of the ECB's monetary policy. Jiménez et al. (2014) have shown how monetary policy affects the composition of the supply of credit, in particular with respect to credit risk. They have analyzed the impact of lower interest rates on banks' risk-taking and have found that a lower overnight interest rate induces banks to engage in higher risk-taking in their lending and encourages lowly capitalized banks to grant more loan applications to risky firms than highly capitalized banks. Moreover, they have found that when the overnight rate is lower, applications granted by lowly capitalized banks also have a higher ex post likelihood of default. ${ }^{7}$ Their analysis suggests that when the monetary policy rate is lower, the intensity of risk-taking is not simply the result of more lending by capital-constrained banks, but is also consistent with risk-shifting (see also Rajan 2006; Allen and Rogoff 2011). Their findings are consistent with other studies that have shown that monetary and macroprudential policies may not be independent (Goodhart 1988; Stein 2012), while others have found, as noted before, that credit booms have the highest ex ante correlation with banking crises (see Schularick and Taylor 2012; Gourinchas and Obstfeld 2012). These findings support the attribution of new responsibilities to central banks in the realm of macroprudential supervision (Diamond and Rajan 2012).

While it is unquestionable, as examined in Chapters 3 and 7, that the loose monetary policies of the ECB (see Fig. 1.4) had an impact on the housing bubble, it is important to emphasize that monetary policy alone did not cause the crisis. Indeed, the initial growth of mortgage risk and the decline in prudential regulation preceded the ECB's loose policies,

\footnotetext{
${ }^{7}$ On the contrary, they found that a lower long-term interest rate and other key macrovariables such as securitization and current account deficits (which entail capital inflows) have no such effects.
} 


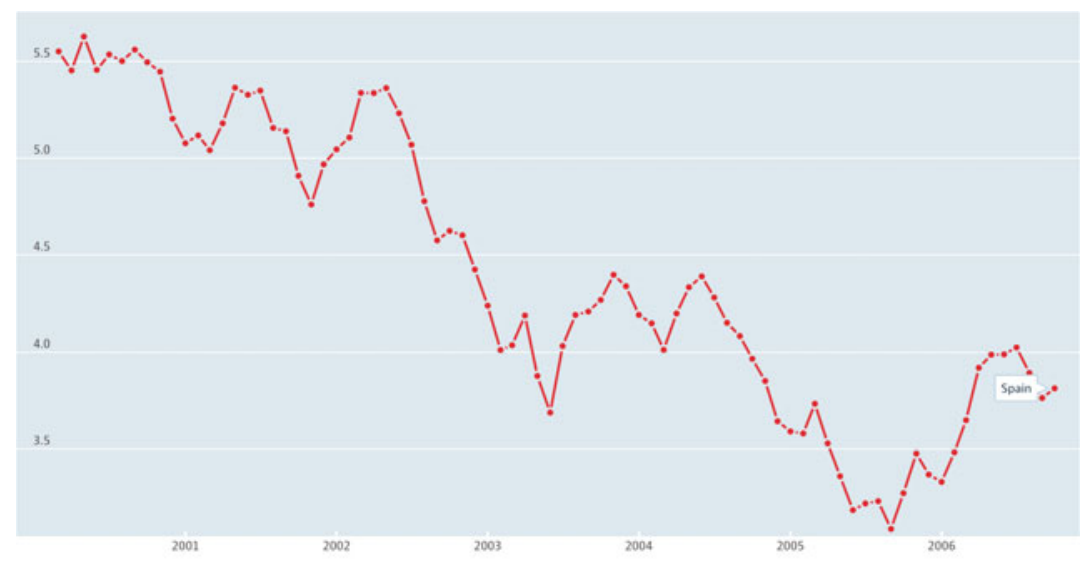

Fig. 1.4 Long-term interest rates. Total, \% per annum, March 2000-October 2006 (Source OECD Main Economic Indicators: Finance)

and the BoS could have countered the effect of the ECB loose monetary policies by increasing capital requirements from banks and cajas. Furthermore, although monetary policy can contribute to the overpricing of real estate assets and the development of bubbles, banking crises require first that banks invest in those overpriced and risky assets, and also that they back those investments with insufficient capital (see Calomiris and Haber 2014, p. 271). Therefore, it is not enough to just account for weaker lending standards and prudential regulatory failures; these banks' decisions need to be explained. Moreover, we also have to explain differences among banks/cajas because not all banking institutions behaved the same way: Most cajas were far more aggressive and reckless in their lending practices than banks. These differences also need to be accounted for. This book builds from those analyses, to show that "banks bargains" created the institutional framework that allowed cajas to lend recklessly and provided the incentives to do so.

Finally, in their recently published book, Copelovitch and Singer (2020) examine why some countries are more prone to systemic bank crises than others, and what makes banks vulnerable under contemporary conditions. They also study banking focusing on politics, but rather than studying the political and public policy preferences of bankers or their political contributions, they focus on the political decisions that shape the 
structure of financial markets. In particular, they analyze two variables: foreign investment into a country and financial market structure (e.g., markets in securities-especially stocks). According to them, banks are embedded in financial markets that are the result of government choices, and they operate in an environment that is shaped by those choices, which in turn would determine their resilience or crisis proneness.

Copelovitch and Singer analyze economic and banking-sector data from 1976 to 2011 , for the 32 countries in the OECD, and they argue that systemic bank failures are more likely when substantial foreign capital inflows meet a financial system with well-developed stock markets. ${ }^{8}$ This is so because banks take on more risk in those environments, which makes them more prone to collapse. They emphasize that it is not just a matter of a few rogue bankers engaging in excessive profit-hunting, but rather the by-product of the historical development of markets, which creates conditions ripe for crisis. They show that while some countries like Canada (which has always had small, regional stock markets and is the only OECD country without a national stock-market regulator) have been able to accommodate and channel capital inflows productively throughout the economy, in others like Germany these capital inflows have led to their banking system to go awry. According to them, this difference is based on the fact that a large securities market is a form of competition for the banking sector, to which banks respond by taking greater risks because they both compete for the business of firms that need to raise money. In countries where the stock markets are small and unsophisticated, there's not much competition and firms go to their banks to financing. However, when stock markets are well developed, banks do not want to lose customers and they assume larger risks. They show that Canadian banks do not face a competitive threat from stock markets the way banks in the United States do, and hence, they can still be Conservative and remain competitive and profitable; by contrast, German national-scale banks have been feeling pressure from a thriving set of regional banks, and they looked at stock markets to improve their competitive advantage and bolster their profits through securities investment, leading to many banking blowups in the last two decades. In order to address these sources

\footnotetext{
${ }^{8}$ The collapse of the Bretton Woods system of international monetary-policy cooperation led to a significant increase in foreign capital movement. From 1990 to 2005 alone, international capital flow increased from $\$ 1$ trillion to $\$ 12$ trillion annually. (It has since slid back to $\$ 5$ trillion, after the 2008 global financial crisis.)
} 
of instability, they advocate for macroprudential regulations for banks to ensure that they are holding enough capital to absorb any losses they might incur.

As it relates to Spain, Copelovitch and Singer claim that the Spanish experience validates their hypothesis. First, they confirm that large capital inflows measured by either net or gross portfolio flows are not always associated with banking instability: Spain was a country with low levels of gross inflows, and yet it experienced frequent banking crises (p. 34). Second, they use the case of Spain in 2003 (with a market/bank ratio of 0.39 in 2003) and compare it with Sweden in 1981 (with a market/bank ratio of -3.75 ) in order to illustrate the substantive significance of their results and to calculate the predicted effect of a 1.5 standard deviation increase in gross portfolio flows on the probability of a banking crisis. They find that "for Spain 2003 the baseline predicted probability of a crisis is 3.2 percent and the estimated first difference effect of a 1.5 standard deviation in gross portfolio flows is extremely large (48.0 percent) and significant at the 95 percent confidence level” (p. 56). ${ }^{9}$ These results confirm their theory that capital inflows are destabilizing only in more securitized financial systems. In other words, capital inflows influence the propensity of banks to take on greater risk, through the assumption of greater insolvency risk and/or through a reduction of capital reserves, depending on the country's domestic financial market structure: at low levels of market/bank ratio. And capital inflows have no correlation with bank capital levels and vice versa. In sum, according to them, capital inflows trigger banking crises not because they cause credit booms, but because they lead banks to reduce the capital holdings and lend to riskier lenders (p. 73).

\section{Methodology}

This book has chosen an historic and institutional approach that considers the objectives of policy-makers and social actors, as well as the way that they interpret existing economic and political conditions. This approach allows the researcher to examine the ways institutions structure the relations among actors and shape their interests and goals, thus constraining political struggles and influencing outcomes (Steinmo et al. 1992, p. 2).

\footnotetext{
${ }^{9}$ For Sweden, they find that the estimated first difference is $3.0 \%$, which is significantly large given that the baseline-predicted probability of a crisis is only $1.6 \%$ (p. 56).
} 
From a methodological standpoint, and following Calomiris and Haber (2014, p. 452), the book is a case study that studies a sequence of events in a particular country, Spain, over long periods of time. It emphasizes the role of narratives in causal inference. This historical analysis allows us to explore the roots of the country's banking problems as well as the antecedents and timing of key banking decisions. This is an appropriate approach to identify causal patterns and develop "structural narratives' which combine the logic of economics and political bargaining with a careful examination of the specific historical events in individual countries." The aim is to show evidence of the key factors that contributed to economic, political, and financial history. While this approach has limitations (i.e., it is based on causal inferences, and being a case study it may not be necessarily representative), it builds on Calomiris and Haber's comparative analysis by emphasizing the role of narratives in causal inference, insisting on the value of narrative evidence, and reinforcing the applicability of the identified patterns to other cases.

In this book, the focus is on the institutions that shape the incentives of individuals and groups. Institutions are crucial because they set the "rules of the game." They determine the capacity of coordination among political and economic actors, and they encourage them to form coalitions to advance common interests. Institutions are also responsible for establishing standards and setting rules, and also for monitoring, rewarding, and/or sanctioning behavior (depending on the case). While banks operate within existing institutional constraints, these institutions are constructed as political solutions to political problems, they are the result of political deals, and they evolve as a result of shifting political and economic circumstances. The problem arises when these political institutions create incentives to develop coalitions that may be detrimental to the wellbeing of a country.

The book also examines coalitions: It looks at domestic coalition (cleavage) formation (Lipset and Rokkan 1967; Moore 1967). The benefited group will gain more political power by way of economic leverage and strategic incentives (Rogowski 1990). But individual actors are also important because they shape outcomes and they have the ability to identify opportunities for forming coalitions and implementing innovations. Indeed, individuals in central positions of power (for instance, in government and/or regulatory agencies) can make a difference for banking outcomes. 
Government leaders should remember that banks and capital markets are also mediated by public institutions and political decisions. Politics are not only desirable but also inevitable in dealing with the political and economic effects of banking crises. This book wants to contribute to this discussion by taking recent changes in the Spanish political economy as a point of departure. It seeks to explore the relationship between institutions and the interests of economic actors and their experiences.

Coalition bargaining is a political process, and strategic actors with their own interests design institutions (Thelen 2004). Institutional change is a political matter because institutions are generated by conflict, they are the result of politics of distribution, and hence they are politically and ideologically construed and depend on power relations (Becker 2009). Institutions are important for banks because they influence interests and impact coalitions, and in a context of structural changes, we have to examine the political settlements that motivate the economic actors.

Finally, most of the research material for this project has been gathered in Spain. In order to pursue this analysis, the author conducted an extensive review of the secondary literature and has interviewed scholars, economic actors, and policy-makers. The author has conducted interviews with leaders of the Spanish banking sector, as well as leaders and representatives of the main political parties. In addition, the author has interviewed former and current high-ranking officials from state agencies: ministry of economics, the BoS, the European Commission, and the European Central Bank (ECB). Finally, the author has conferred with leading scholars and specialists in politics, finances, and economics in Spain and the United States. Finally, primary and secondary sources of data come from the libraries and records of selected Spanish government departments and international institutions, like the ECB, the World Bank, the OECD, and the International Monetary Fund (IMF). 


\section{Structure of THE SPANish \\ FinANCIAL SySTEM I986-2005 $5^{10}$}

Since Spain joined the European Union (EU) on January 1, 1986, the Spanish Financial System (SFS) has been adapting to the European context of which it is part. ${ }^{11}$ The regulatory organs of the SFS are all the institutions with competences to dictate legal norms (i.e., the government, Congress, and the Ministry of Economy), while the supervisory organs are the BoS and the National Stock Market Commission (Comision Nacional del Mercado de Valores, CNMV). The BoS is the central supervisory institution. Regulated by the 13/1994 Law of Autonomy of the Bank of Spain (which has been subsequently partially modified), the Bank is in charge of the supervision of all credit institutions. It shared some competences with the autonomous communities, which also had supervisory power over the savings banks (Cajas de Aborro) and credit cooperatives. Finally, the Comisión Nacional del Mercado de Valores (CNMV), created by the $24 / 1988 \mathrm{Law}$, has been the institution in charge of supervision and inspection of stock markets and the activities of legal and physical people involved in these markets.

Most of the cajas were established in the nineteenth century as pawnshops with the support of the Catholic Church and/or local municipalities, with the aim to redistribute their profits through social work (they dedicated a significant portion of their provisions, typically over $20 \%$ to social causes) (see Güell 2001). Overtime most of them came under the control of the regional and local governments who often used them to advance their political agendas. They were regulated by both the national government (in charge of the basic norms) and the autonomous communities' governments (in charge of the application and development of the rules established by the central government). Political institutions (parties and unions) participated in the governing bodies of the cajas.

As noted throughout the book, the distinctive regulatory framework that separates cajas from commercial banks was a crucial factor in explaining the differences in performance between the cajas and commercial during the 2008 crisis. Indeed, in the last decades cajas made a push to

${ }^{10}$ From: "Why the Spanish Financial System Survived the First Stage of the Global Crisis?" Governance (Article first published online: November 6, 2012. Volume 26, Issue 4. October 2013, pp. 631-56).

${ }^{11}$ From Royo (2013, pp. 179-81). 
increase their market share, and they expanded aggressively beyond their traditional markets competing with traditional commercial banks to offer real estate loans. When the real estate bubble collapsed after 2007, many of them accumulated billions of euros of loans at risk of default and were forced to require state support.

Prior to the liberalization of the late 1980s and 1990s, the SFSs (like those of Greece and Italy) was typical credit-based Mediterranean system, characterized by extensive interventionism, state control over the banking system, and underdeveloped capital markets (Pérez and Westrup 2010). The role of financial institutions was to provide funding to contribute the process of economic development and industrialization (Pérez 1997; Lukauskas 1997), and bank deposits were turned into low-interest credit for industrial enterprises and the government (Deeg and Pérez 2000). The oligopolistic nature of the sector generated significant costs for Spanish firms outside the finance sector (Pérez 1997).

The liberalization of the sector started in the second half of the 1980s, driven by the country's integration in the European Community and the subsequent European Single Market program. In Spain's case, the process of financial liberalization was also part of the BoS's effort to achieve effective disinflation (Pérez and Westrup 2010). The European integration process, and particularly the creation of the Single Market and the European Monetary Union, has been a driving factor in subsequent developments. While financial regulations were still the responsibility of the national governments, in reality over the last two decades there has been a harmonization process throughout all the member states. This process led to the liberalization, modernization, consolidation, and opening up of the system.

In Spain, the regulation and supervision of the SFS seek two main objectives: to guarantee the correct functioning of its markets and to protect the consumers of financial services. Regulation, defined as the development of the norms that rule the activities of financial markets and institutions, has to be distinguished from supervision: the guardianship of the fulfillment of the norms. The regulatory organs of the SFS are all the institutions with competences to dictate legal norms, i.e., the government, Congress, and the Ministry of Economy, while the supervisory organs are the BoS and the National Stock Market Commission (Comisión Nacional del Mercado de Valores, CNMV) (see Fig. 1.5).

Financial institutions were very important for the Spanish economy because they accumulated approximately $36 \%$ of the total financial assets 


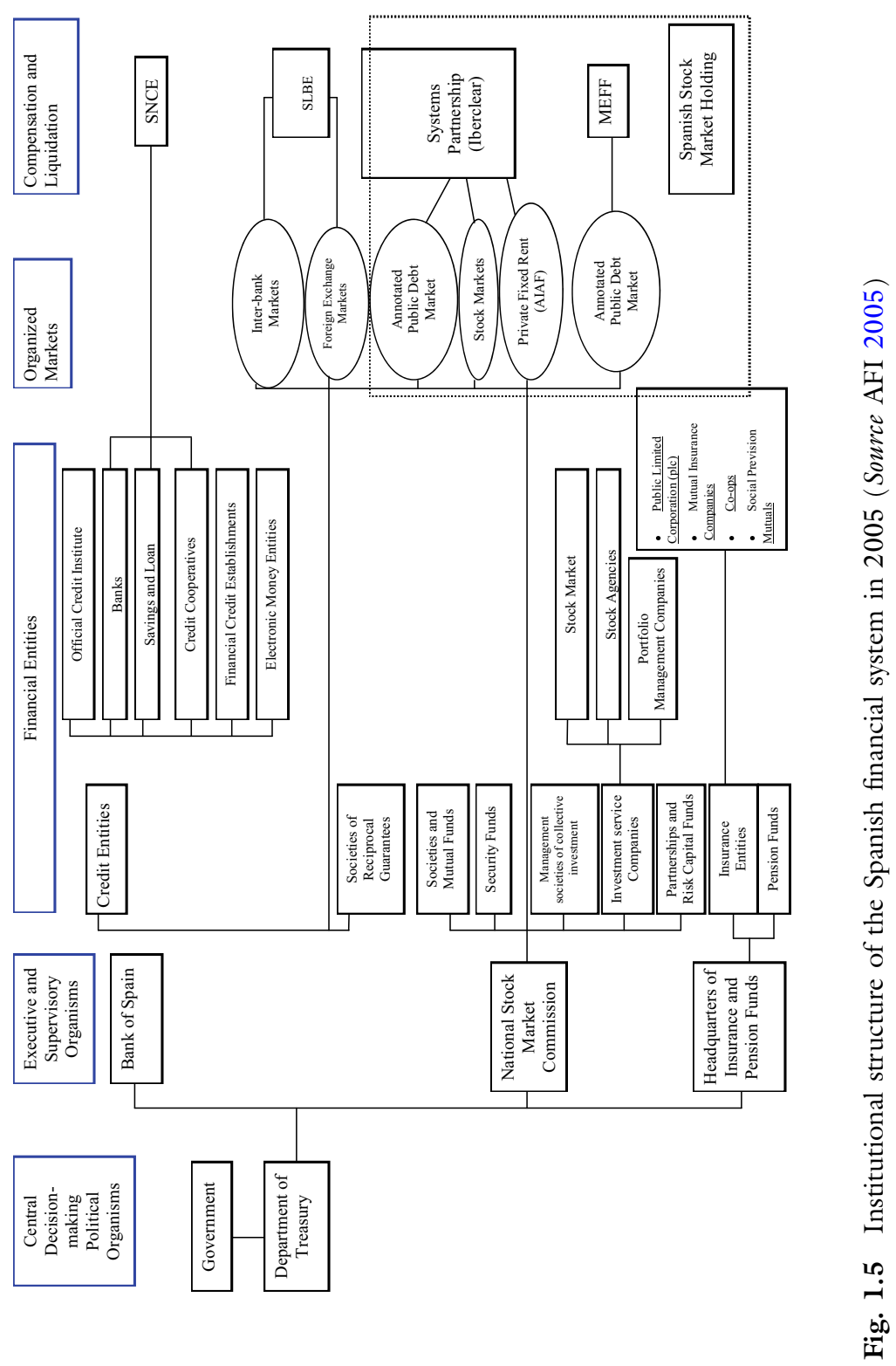


and liabilities prior to the crisis. Credit institutions concentrated approximately $94 \%$ of the credit process, which illustrates the high relative weight of financial intermediation in the Spanish economy. Indeed, the SFS was considered as highly bankarized (bancarizado) given the strong direct or indirect weight of credit institutions, particularly banks and cajas. Yet, the degree of financialization ${ }^{12}$ of the sector was relatively low prior to the crisis and the majority of banks' assets were loans to customers, and a significant part of bank assets involved Spanish government securities, which were considered among the safest possible asset investments. This relatively low degree of financialization of Spanish banks (like Italian and Greek ones) can be explained by the slow evolution of the NFS and Spanish banks' reluctance to change a business model that has been consistently successful for decades.

Based on Hardie and Howarth's banking typology (2013), corporate finance in Spain cannot be considered 'market based. ${ }^{13}$ Indeed, European Central Bank (ECB) data show that assets are really very much not market based. According to the ECB, data customer loans as a percentage of assets were $67.31 \%$ at the end of 2007, a much higher percentage compared to other countries, such as the UK, Germany, or France. This would place Spain very low on the market-based banking category.

Furthermore, securitization provided collateral for about $20 \%$ of bank lending in Spain prior to the crisis. This was actually moderately high in comparative terms (for instance, in France it was only 1\%). Thus, a lot of the Spanish credit boom was fed by the securitization of liabilities, which allowed Spanish banks to lend more. This was not off-balance sheet, but the result (increased lending) was similar to what we saw in other countries like the UK (although about 50\% less in GDP terms). Thus marketbased banking was still pretty important to Spain. According to the IMF, at the end of 2007, cross-border liabilities as a percentage of GDP represented only $60.6 \%$, a much lower figure than that of countries such as

${ }^{12}$ Financialization is defined as the trading of risk, and it is operationalized by looking at Spanish banks' assets (i.e., the size of the trading book and the presence of toxic assets) and liabilities (i.e., the funding base of banks), their reliance on wholesale market rather than retail deposits for funding, the securitization of lending, and the use of structured investment vehicles (SIVs).

13 The concept of "market-based" banking (MBB) considers the extent to which the banks' ability to supply credit to the economy is driven by market pressures on both the asset and liability sides of their balance sheets. 
France $(157.6 \%)$ or Germany (143.3\%). International liabilities as a percentage of total liabilities represented $24.1 \%$ (versus $66.1 \%$ in the UK or $77.7 \%$ in Ireland).

Finally, prior to the crisis, according to the BoS data, on the liabilities side Spanish banks were traditionally very active in capital markets, relaying particularly on the interbanking markets for their funding (on average about $20 \%$ of the total), while cajas and credit cooperatives, which were more successful capturing resources from their customers were not so dependent on those markets (only around 7\%). Spanish banks lent more than what they got in deposits, which forced them to rely on wholesale markets to fill the gap. This forced them during the crisis, as we discuss throughout the book, to rely heavily on the ECB.

\section{The Financial Bailout}

As mentioned above, the crisis of the financial system in Spain led to a European bailout in 2012 (see Royo 2013). As part of its historical analysis of the Spanish banking sector, this book seeks to explain how that banking crisis happened. The main detonator that led to the bailout was Bankia's rescue, which highlighted concerns that the level of provisions that Spanish banks had taken against distressed property portfolios was too low. At the same time, concerns about the fiscal situation of the country (public debt had doubled since the crisis started from $35.5 \%$ of GDP at the end of the first quarter of 2008 to $72.1 \%$ at the end of the first quarter of 2012) and the interconnectedness between sovereign issuer and banks (the infamous "doom loop") pushed Spanish yields up and led to growing concerns about the need for a bailout. In the end, the intensification of the financial crisis led to a deepening sovereign crisis, and since Spain's banking system was perceived as systemically important for the Eurozone because the country had about 450 billion euros of deposits from foreign companies and individuals, the European (and IMF) leaders decided to intervene.

Prior to the bailout, investors perceived those concerns and they were punishing Spanish banks and Spain's sovereign. The performance of Spanish banks' stock reflected those worries as well: between mid-March and the end of June of 2012, Santander and BBBA's stock declined about $30 \%$. At the same time, Spain's cost of borrowing kept increasing and the spread on Spanish ten-year bonds over German Bunds hit new European highs in late May 2012, climbing to 511 points, while yields of ten-year 
bonds moved above $6.5 \%$ (reaching $6.9 \%$ on June 14 ), and moving closer to the $7 \%$ level that was widely considered unsustainable, and which led to bailouts for Greece, Portugal, and Ireland.

Yet, despite these alarming signs, as late as Spring 2012, the Spanish government and PM Rajoy insisted that the country would not need international bailout for its banks. On April 12, Mr. Rajoy stated that "talking about a rescue makes no sense... Spain is not being rescued; Spain can't be rescued. There is no intention and no need and so Spain will not be rescued." Rajoy was also on record stating that "we are not going to let any regional government fall, or any bank fall, because they can't ... if that happens the country will fall." 14 This followed the repeated statements of the members of the government that Spain would not take any form of international rescue.

By early June 2012, however, it was becoming clear that despite all the denials, a rescue was inevitable and that Spain would in fact need a financial bailout. The government's attempts to force the EU and BCE's hands (the budget minister, Cristobal Montoro, responded to a question about whether Spain needed a bailout with a veiled threat: "those with the most interest in whether Spain does all right are the holders of debt, who have to be repaid in full and have that right," and Minister Guindos was on the record stating that the battle for the euro was going to be waged in Spain ${ }^{15}$ ), and its insistent demand for help from its European partners only exasperated them and intensified concerns in European capitals that it was only considerations over the political stigma associated with a bailout, rather than the policy constraints that Brussels would include on it, that was keeping the Spanish government from accepting aid that was on the table.

Spain's risk premium - the difference between its bond yields and those of Germany-continued soaring after the Bankia nationalization, adding pressure to the government, and Bankia's shares plunged. By June 5, the severity of the situation was finally creeping in and the government was already admitting (in the words of Mr. Montoro) that given the high perceived risk of its sovereign debt, Spain did "not have the doors of the markets open," and this despite the fact that it was planning to auction

${ }^{14}$ See “Doubts Emerge over Spain's Leaders," Financial Times, April 13, 2012.

15 See "Defiant Spain to Test the Bond Market," Financial Times, June 1, 2012. 
up 2 billion euros of bonds that same week. Mr. Rajoy, for his part, continued insisting on the need for a banking union and Eurobonds, stating during a senate session that Europe "needs to support those that are in difficulty ... The most important thing is we have a problem of financing, of liquidity and debt sustainability." 16 Germany still refused to provide aid unless there was a formal request from the Spanish government.

Finally, on Saturday, June 9, following a few days of fierce official negations, the government asked the EU for funds to recapitalize its struggling banking sector at a conference call between the Eurozone's 17 finance ministers. It agreed to accept a bailout of up to $\$ 125$ billion, nearly three times the $\$ 46$ billion in extra capital that the IMF said it was the minimum the banking sector needed to guard against the deepening of the country's economic crisis. The decision also aimed at quelling rising financial turmoil ahead of the Greek parliamentary election scheduled for June 17. This decision made Spain the fourth and largest European country to agree to accept emergency assistance (albeit in this case only for the country's financial sector).

The European statement on the aid gave few details, which initially allowed the government to claim that it was not a "rescue" package, and that it was not subject to the conditionality and supervision by the troika (EU, IMF, and ECB) that characterized the other three rescue packages of Greece, Ireland, and Portugal. In Spain, the announcement was made by Minister Guindos, which caused a political storm and forced PM Rajoy to give an impromptu press conference the day after, on Sunday, June 10, before he departed to watch the Spanish football national team play a EuroCup game in Poland. Guindos announced that "what we are asking is financial support, and this has absolutely nothing to do with a full bailout," and added that the terms of the emergency loan would be "very favorable," and that "the problem that we face affects about $30 \%$ of the Spanish banking system." 17 The amount of the financing was expected to be completed after the two consulting firms had been hired to look at the bank accounts published their audit report on June 21 . The funds would be channeled through the Spanish bank bailout fund, the FROB, and the

${ }^{16}$ See "Spain Makes Explicit Plea for Bank Aid," Financial Times, June 5, 2012.

${ }^{17}$ See "Spain to Accept Rescue from Europe for Its Ailing Banks," New York Times, June 9, 2012; and "Spain Seeks Eurozone Bailout," Financial Times, June 10, 2012. 
Spanish government would ultimately be responsible and had to sign the memorandum of understanding and the conditions that came with it.

The market's response to the bailout package was initially sanguine. While observers praised the decisive pre-emptive action of European leaders (something relatively unusual during the crisis), and the fact that the aid was directed to the banks and that the amount was much larger than estimated to give some margin in the case of further need, there was disappointment regarding the failure to inject the money directly into the banks as equity. ${ }^{18}$ The model proposed for the aid failed to recognize the crucial link between sovereign debt and the banks. Spanish banks accounted for a third of Spanish sovereign bonds, nearly double the tally before the crisis started (they had purchased 83 billion euros between December 2011 and June 2012). As in Greece where the sovereign debt dragged down the banks, this made them very vulnerable to a potential sovereign debt crisis, which was becoming increasingly more likely in Spain, thus intensifying the "doom loop." Consequently, after an initial market rally, the Spanish bond continued jumping higher and reached a new record, very close to $7 \%$, just four days after the announcement of the bailout, demonstrating that investors were growing increasingly anxious about Spain's ability to pay back its debts.

\section{Main Argument of the Book}

The 2010 banking crisis in Spain confirms a long-standing tenant: Banks or banking systems collapse when they meet two conditions: They take on too much risk in their loans and investments, and they do not have sufficient capital on reserve to absorb the losses associated with their risky investments and loans (Calomiris and Haber 2014, p. 207). Indeed, the cause of the 2012 crisis in Spain was rooted in policies that eroded underwriting standards and weak prudential regulation.

As we will see later in the book, the banking crisis affected in particular a set of financial institutions, the cajas (savings and loans, S\&L). Indeed, with a few relatively small exceptions, the Spanish financial crisis has been

${ }^{18}$ See Patrick Jenkins, “'Doom Loop' Takes the Fizz Out of Madrid's Brief Euphoria," Financial Times, June 12, 2012, 2; and Andrew Ross Sorkin, "Why the Bailout in Spain Won't Work,' New York Times, June 12, 2012, B1. 
a crisis of the cajas. These institutions borrowed short term from depositors and then lend long term on fixed-rate mortgages. ${ }^{19}$ The success of this model, however, was based on two conditions: low inflation volatility and discipline from depositors who would withdraw their deposits if the managers acted imprudently. However, by the 2000s, the context in which these institutions operated had changed markedly and the 2007 global financial crisis hit them hard because they were very dependent on wholesale funding.

Yet, government protection of cajas (part of the bank bargains that we will examine) had insulated them from the consequences of their own risk-taking and facilitated the reckless decisions that led to their downfall. When the real estate market collapsed after 2007, wholesale funding dried up and their funding costs skyrocketed, which caused significant problems because they had to pay more for capital, and they held mortgages that (many of which went into default as a result of the crisis) still earned only low fixed interest rates of return. This brought several of them to the point of insolvency. If their vulnerability, driven by their high reliance on the real estate market and wholesale funding, had been recognized and addressed in the years prior to the crises through cajas' closures, shrinkage, or consolidation, the crisis for the cajas would have been significant but not as devastating as it ended up being. As losses started to pile up the Spanish government, supervisory agencies should have shut down insolvent ones or forced them to raise additional capital. Yet, they ignored or minimized the signs and looked the other way, postponing the day of reckoning. But in doing so, they ensured that the final outcome would be much worse.

In many Spanish cajas, there was a failure of risk management, which led to an increase in risky lending and to inadequate levels of capital cushions. The question remains how it was that so many cajas ended up making so many risky loans while maintaining insufficient capital to protect themselves against insolvency. What were the processes by which cajas' portfolios became increasingly risky, and by which increased risk in bank assets was not adequately matched by increasing amounts of capital in reserve.

This book will argue, following Calomiris and Haber (2014), that institutional and regulatory frameworks favored both the government and other privileged actors' access to finance at the expense of an environment

${ }^{19}$ See Calomiris and Haber (2014, pp. 199-201). 
conducive to a stable banking system. Indeed, political institutions have structured the incentives of bankers and political and economic actors to form coalitions that shaped regulations and policies in their favor This institutional framework was the result of political choices that made it vulnerable, because prudent lending practices continued being influenced by the desires of the groups that were in control of the government, who often channeled credit to groups that were considered politically crucial. Therefore, it is not surprising that banks have been fragile and crises prone.

\section{Organization OF THE BOOK}

The book continues in Chapter 2 with an overview of the origins of the Spanish banking system prior to the twentieth century. It shows the role of the state in the development of the Spanish banking system, and how financial mismanagement contributed to the decline of the country prior to the twentieth century. It also examines the 'bank bargains' that took place during that era, which ultimately led to the development of a fragile banking system and recurrent banking crises.

Chapter 3 examines the evolution of the Spanish banking system in the twentieth century and analyzes the causes of the mid-1970s and early 1980s banking crisis. It shows how the banking sector was transformed and modernized, growing from an underdeveloped structure into a comparatively modern sector. However, successive governments continued establishing institutional and regulatory frameworks that favored both the government and other privileged actors' access to finance at the expense of an environment conductive to a stable banking system which ultimately led to a systemic baking crisis in the 1970s.

Chapter 4 analyzes the overall economic crisis that started in 2008 in Spain. It is impossible to disentangle the 2008 banking crisis from the overall economic crisis that affected the country at the same time. As the economic crisis intensified, Spain's banking sector could not escape its dramatic effects. This chapter looks at the performance of the Spanish economic throughout the 1990s and the first decade of the twentieth century. It examines the reasons for the success of the Spanish economy in the 1990s and provides an overview of the main causes of the 20082013 crisis and the governments' responses.

Chapter 5 analyzes the impact of the global crisis on the SFS between 2008 and 2010. It shows that, overall, the performance of the largest 
Spanish financial institutions was positive. The chapter examines why and outlines some lessons from the Spanish experience. It contends that this response was largely driven by institutional, political, and cultural factors. Finally, the chapter considers the Spanish experience within the framework of the VoC literature. While financial capitalisms have converged toward deregulation as a result of the combined processes of globalization and European integration, this chapter shows that differences persist. Indeed, in the case of Spain, the crisis led to extensive regulatory intervention that served to reinforce the pre-existing model.

Chapter 6 examines the subsequent impact of the economic crisis on the SFS, as well as the banking bargains that ultimately led to the financial bailout. In addition, it focuses on the following variables: deteriorating economic conditions; the implosion of the real estate market; the dependence on wholesale funding; weaknesses in the regulatory framework; and the role of the BoS.

Most of the analyses on the crisis in Spain have concerned themselves with phenomena like mismanaged banks, excessive debts, the bubble in the real estate sector, or the loss of competitiveness. Others have sought to explain the crisis as a by-product of EMU integration. Chapter 7 moves beyond those explanations and argues that a fundamental reason for the economic and financial crisis is rooted in the process of institutional degeneration that preceded the crisis. It analyzes the deteriorating performance of Spanish institutions to explain that reversal.

The concluding chapter provides an overview of the main arguments to explain the fragility of the Spanish banking system. It shows how domestic social, political, and economic factors have been crucial to understand coalition formations and policy choices in Spain. These coalitions have not been neutral, and they have influenced the stability and resilience of the Spanish banking system and its ability to provide credit. It also outlines some lessons from the Spanish experience and analyzes the main implications of the financial crisis.

\section{REFERENCES}

Acemoglu, Daron, and James Robinson. Why Nations Fail: The Origins of Power, Prosperity and Poverty. New York: Random House, 2012.

AFI (Analístas Financieros Internacionales). Guía del Sistema Financiero Español. Madrid: AFI, 2005.

Allen, Franklin, and Kenneth Rogoff. "Asset Prices, Financial Stability and Monetary Policy." In The Riksbank's Inquiry into the Risks in the Swedish Housing 
Market, edited by Per Jansson, and Mattias Persson, 189-218. Stockholm: Sveriges Riksbank, 2011.

Amable, Bruno. The Diversity of Modern Capitalism. Oxford: Oxford University Press, 2003.

Amri, Puspa D., Greg M. Richey, and Thomas D. Willet. "Capital Surges and Credit Booms: How Tight Is the Relationship." Open Economics Review 27, no. 4 (2016): 637-70.

Armigeon, Klaus, and Lucio Baccaro. "The Sorrows of Young Euro." In Coping with the Crises, by Nancy Bermeo and Jonas Pontusson, 162-98. New York: Russell Sage Foundation, 2012.

Avgouleas, Emilios, and Charles Goodhart. "Critical Reflections on Bank BailIns." Journal of Financial Regulation 1, no. 1 (March 2015): 3-29.

Barrón, Iñigo. El Hundimiento de la Banca. Madrid: Catarata, 2012.

Becker, U. Open Varieties of Capitalism: Continuity, Change and Performance. NY: Palgrave, 2009.

Bermeo, N., and Jonas Pontusson. Coping with the Crises. New York: Russell Sage Foundation, 2012.

Caballero, Julián A. "Do Surges in International Capital Inflows Influence the Likelihood of Banking Crises?" The Economic Journal 126, no. 591 (2016): 281-316.

Calomiris, Charles W., and Stephen H. Haber. Fragile by Design: The Political Origins of Banking Crises \& Scarce Credit. Princeton: Princeton University Press, 2014.

Cameron, David. "European Fiscal Responses to the Great Recession." In Coping with the Crises, by Nancy Bermeo and Jonas Pontusson, 91-129. New York: Russell Sage Foundation, 2012.

Chinn, Menzie D., and Jeffry A. Frieden. Lost Decades: The Making of America's Debt Crisis and the Long Recovery. New York: W.W. Norton \& Company, 2011.

Copelovitch, Mark, and David A. Singer. Banks on the Brink: Global Capital, Securities Markets, and the Political Roots of Financial Crises. New York: Cambridge University Press, 2020.

Deeg, Richard, and Sofía Pérez. "International Capital Mobility and Domestic Institutions: Corporate Finance and Governance in Four European Cases." Governance 13, no. 2 (2000): 119-53.

Deeg, Richard, and Susanne Luetz. "Internationalisation and Financial Federalism: The United States and Germany at the Cross Roads?" Comparative Political Studies 33, no. 3 (2001): 374-405.

Della Sala, Vincent. "The Italian Model of Capitalism: On the Road between Globalization and Europeanization?" Journal of European Public Policy 11, no. 6 (December 2004): 1041-57. 
Diamond, Douglas W., and Raghuram G. Rajan “Illiquid Banks, Financial Stability, and Interest Rate Policy." Journal of Political Economy 120 (2012): 552-91.

Eurostat/European Commission. Enterprises in Europe: Sixth Report. Luxembourg: Office of Official Publications of the European Communities, 2001.

Ferguson, Neil. The Great Degeneration. New York: Penguin Press, 2013.

Fishman, Robert. "Rethinking the Iberian Transformations: How Democratization Scenarios Shaped Labor Market Outcomes." Studies in Comparative International Development 45, no. 3 (2010): 281-310.

Germain, Randall. "Governing Global Finance and Banking." Review of International Political Economy 19, no. 4 (2012): 530-35.

Goodhart, Charles A. E., Anil K. Kashyap, Dimitrios P. Tsomocos, and Alexandros P. Vardoulakis. "Financial Regulation in General Equilibrium." NBER Working Papers Series. Working Paper 17909 (March 2012). http://www. nber.org/papers/w17909.

Goodhart, Charles. The Evolution of Central Banks. Cambridge, MA: MIT Press, 1988.

Goodhart, Charles A. E., Tsomocos, P. Dimitrios, and Alexandros P. Vardoulakis. "Modeling a Housing and Mortgage Crisis." In Financial Stability, Monetary Policy, and Central Banking, edited by Rodrigo A. Alfaro. Santiago, Chile: Central Bank of Chile, 2010.

Gourinchas, Pierre-Olivier, and Maurice Obstfeld. "Stories of the Twentieth Century for the Twenty-First." American Economic Journal: Macroeconomics 4 (2012): 226-65.

Güell, Joan. "Las Cajas de Ahorro en el Sistema Financiero Español. Trayectoria Histórica y Realidad Actual.” Paper presented at the Universidad de Zaragoza, during the Jornadas sobre La singularidad de las cajas de aborros españolas. May 28, 2001.

Haggard, Stephan, and Jongryn Mo. "The Political Economy of the Korean Financial Crisis." Review of International Political Economy 7, no. 2 (2000): 197-218.

Hall, Peter, and David Soskice. Varieties of Capitalism. New York: Oxford University Press, 2001.

Hancké, Bob, Martin Rhodes, and Mark Thatcher, eds. Beyond Varieties of Capitalism: Contradictions, Complementarities, and Change. Oxford: Oxford University Press, 2007.

Hardie, Ian. "How Much Can Governments Borrow?" Financialization and Emerging Markets Government Borrowing Capacity." Review of International Political Economy 18, no. 2 (2013): 141-67.

Hardie, Iain, and David Howarth. "Market-Based Banking and the Financial Crisis." Mimeo: Paper present at the University of Victoria, 2013. 
Jabko Nicolas, and Elsa Massoc. "French Capitalism under Stress: How Nicolas Sarkozy Rescued the Banks." Review of International Political Economy 19, no. 4 (2012): 562-95.

Jackson, Gregory, and Richard Deeg. "How Many Varieties of Capitalism? From Institutional Diversity to the Politics of Change." Review of International Political Economy 15, no. 4 (2008): 679-708.

Jiménez, Gabriel, Ongena, Steven, Peydró, José Luís, and Saurina, Jesús, "Hazardous Times for Monetary Policy: What do Twenty-Three Million Bank Loans Say about the Effects of Monetary Policy on Credit Risk-Taking?" Econometrica 82, no. 2 (2014): 463-505.

Kahler, Miles, and David Lake. The Great Recession in Comparative Perspective. Ithaca: Cornell University Press, 2013.

Kaminsky, Graciela, and Carmen Reinhart. "The Twin Crises: The Causes of Banking and Balance-of-Payments Problems." The American Economic Review 89, no. 1 (1999): 473-500.

Kindleberger, Charles. The World in Depression 1929-1939. Berkeley: University of California Press, 1973.

Kindleberger, Charles. Manias, Panics, and Crashes: A History of Financial Crises. New York: Wiley, 1996.

King, Robert G., and Ross Levine. "Finance and Growth: Schumpeter Might Be Right.” Quarterly Journal of Economics 108 (1993): 717-37.

Lipset, Seymur Martin, and Stein Rokkan. Party Systems and Voter Alignment. New York: Free Press, 1967.

Lukauskas, Arvid. Regulating Finance. Ann Arbor: Michigan University Press, 1997.

Mabbet, Deborah, and Waltraud Schelke. "What Difference Does Euro Membership Make to Stabilization? The Political Economy of International Monetary Systems Revisited." Review of International Political Economy 22, no. 3 (June 2015): 508-34.

Maddaloni, Angela, and Peydró, José Luís. "Bank Risk-Taking, Securitisation, Supervision and Low Interest Rates: Evidence from the Euro-Area and the U.S. Lending Standards." The Review of Financial Studies 24, no. 6 (2011): 2121-65.

Mahoney, James, and Kathleen Thelen. Explaining Institutional Change: Ambiguity, Agency, and Power. New York: CUP, 2009.

Major, Aaron. "Neoliberalism and the New International Financial Architecture." Review of International Political Economy 19, no. 4 (2012): 536-61.

Minsky, Hyman. Can 'It' Happen Again: Essays on Instability and Finance. New York: M.E. Sharpe, 1982a.

Minsky, Hyman. "The Financial-Instability Hypothesis: Capitalist Processes and the Behavior of the Economy." In Financial Crises: Theory, History, and 
Policy, edited by Charles Kindleberger and Jean Pierre Laffargue. New York: Cambridge University Press, 1982b.

Molina, Oscar, and Martin Rhodes. "Conflict, Complementarities and Institutional Change in Mixed Market Economies." In Beyond Varieties of Capitalism, edited by B. Hancké, M. Rhodes, and M. Thatcher, 223-53. Oxford: Oxford University Press, 2007.

Molinas, César. Qué Hacer con España. Madrid: Imago Mundi, 2013.

Moore, Barrington. Social Origins of Dictatorship and Democracy: Lord and Peasant in the Making of the Modern World. New York: Beacon Press, 1967.

Mosley, Layna. "Attempting Global Standards: National Governments, International Finance, and the IMF's Data Regime." Review of International Political Economy 10, no. 2 (2003): 331-62.

OECD. OECD Historical Statistics 1970-1999. Paris: OECD, 2000.

Ortega, Andrés, and Angel Pascual-Ramsay. ¿Qué nos ha pasado? Madrid: Galaxia Gutemberg, 2013.

Pérez, Sofía A. Banking on Privilege. New York: Cornell University Press, 1997. Pérez, Sofía A., and Jonathan Westrup. "Finance and the Macroeconomy: The Politics of Regulatory Reform in Europe." Journal of European Public Policy 17, no. 8 (2010): 1171-92.

Portes, Richard. "Global Imbalances." In Macroeconomic Stability and Financial Regulations: Key Issues for the G20, edited by Mathias Dewatripont, Xavier Freitas, and Riichard Portes. London: CEPR, 19, Vol. 19, 2009.

Quaglia, Lucia, and Sebastián Royo. "Banks and the Political Economy of the Sovereign Debt Crisis in Italy and Spain." Review of International Political Economy 22, no. 3 (2015): 485-507.

Rajan, Raghuram G. "Has Finance Made the World Riskier?" European Financial Management 12 (2006): 499-533.

Reinhart, Carmen M., and Kenneth Rogoff. This Time Is Different: Eight Centuries of Financial Folly. New York: Princeton University Press, 2009.

Reinhart, Carmen M., and Kenneth Rogoff. "From Financial Crash to Debt Crisis." American Economic Review 101 (August 2011): 1676-706

Rogowski, Ronald. Commerce and Coalitions: How Trade Affects Domestic Political Alignments. Princeton, NJ: Princeton University Press, 1990.

Royo, Sebastián. From Social Democracy to Neoliberalism. New York: St. Martin's Press, 2000.

Royo, Sebastián. Varieties of Capitalism in Spain. New York: Palgrave, 2008.

Royo, Sebastián. "A 'Ship in Trouble' The Spanish Banking System in the Midst of The Global Financial System Crisis: The Limits of Regulation." In Market-Based Banking, Varieties of Financial Capitalism and the Financial Crisis, edited by Iain Hardie and David Howarth. New York: Oxford University Press, 2013. 
Schmidt, Vivien. The Futures of European Capitalism. New York: Oxford University Press, 2002.

Schmidt, Vivien. "Putting the Political Back into Political Economy by Bringing the State Back Yet Again." World Politics 61, no. 3 (2009): 516-48.

Schoenmaker, Dirk. "The Trilemma of Financial Stability." Paper prepared for CFS-IMF Conference: A Financial Stability Framework for Europe: Managing Financial Soundness in a an Integrating Market. Frankfurt, 26 September 2008.

Schoenmaker, Dirk. “The Financial Trilemma." Economics Letters 111 (2011): 57-59.

Schularick, Moritz, and Alan M. Taylor. "Credit Booms Gone Bust: Monetary Policy, Leverage Cycles, and Financial Crises, 1870-2008." American Economic Review 102 (2012): 1029-61.

Skocpol, Theda. States and Social Revolutions. New York: Cambridge University Press, 1979.

Stein, Jeremy C. "Monetary Policy and Financial Stability Regulation." The Quarterly Journal of Economics 127 (2012): 57-95.

Steinmo, Sven, Kathleen Thelen, and Frank Longstreth, eds. Structuring Politics: Historical Institutionalism in Comparative Analysis. New York: Cambridge University Press, 1992.

Stiglitz, Joseph. "Capital Market Liberalization, Economic Growth, and Instability." World Development 28, no. 6 (2000): 1075-86.

Taylor, Alan. "On the Costs of Inward-Looking Development: Price Distortions, Growth, and Divergence in Latin America." Journal of Economic History 58 (March 1998): 1-28.

Thatcher, Mark. Internationalisation and Economic Institutions: Comparing the European Experience. Oxford: Oxford University Press, 2007.

Thelen, Kathleen. How Institutions Evolve: The Political Economy Skills in Germany, Britain, the United States and Japan. New York: Cambridge University Press, 2004.

Torrero, Antonio. “ La formación de los tipos de interés y los problemas actuales de la economía española." Economistas. Madrid no. 39, 1989.

Weiss, Linda (ed.). States in the Global Economy: Bringing Domestic Institutions Back In. Cambridge: Cambridge University Press, 2003.

Zysman, John. Governments, Markets, and Growth: Financial Systems and Politics Industrial Change. Ithaca, NY: Cornell University Press, 1983. 